\title{
Quarter-level analyses of the associations among subclinical intramammary infection and milk quality, udder health, and cheesemaking traits in Holstein cows
}

\author{
S. Pegolo, ${ }^{1 *} \odot$ R. Tessari, ${ }^{2}$ V. Bisutti, ${ }^{1}$ A. Vanzin,,${ }^{1}$ D. Giannuzzi, ${ }^{1} \oplus$ M. Gianesella, ${ }^{2} \odot$ A. Lisuzzo, ${ }^{2} \odot$ E. Fiore, ${ }^{2} \odot$ \\ A. Barberio, ${ }^{3} \odot$ E. Schiavon, ${ }^{3}$ E. Trevisi, ${ }^{4,5} \odot$ F. Piccioli Cappelli, ${ }^{4,5}$ (․ Gallo, ${ }^{1} \odot$ P. Ruegg, ${ }^{6} \odot$ R. Negrini, ${ }^{4}$ \\ and A. Cecchinato ${ }^{1}$ (1) \\ ${ }^{1}$ Department of Agronomy, Food, Natural Resources, Animals and Environment (DAFNAE), University of Padova, Viale dell' Università 16, 35020, \\ Legnaro (PD), Italy \\ 'Department of Animal Medicine, Productions and Health, University of Padua, Viale dell' Università, 16, 35020, Legnaro (PD), Italy \\ ${ }^{3}$ Istituto Zooprofilattico Sperimentale delle Venezie, Sezione Territoriale di Padova, 35020, Legnaro (PD), Italy \\ ${ }^{4}$ Department of Animal Science, Food and Nutrition - DIANA, Università Cattolica del Sacro Cuore, 29122, Piacenza, Italy \\ ${ }^{5}$ Research Center Romeo and Enrica Invernizzi for Sustainable Dairy Production (CREI), Faculty of Agricultural, \\ Food and Environmental Sciences, Università Cattolica del Sacro Cuore, 29122, Piacenza, Italy \\ ${ }^{6}$ Department of Large Animal Clinical Sciences, College of Veterinary Medicine, Michigan State University, East Lansing 48824
}

\section{ABSTRACT}

In this study, we investigated associations among subclinical intra-mammary infection (IMI) and quarter-level milk composition, udder health indicators, and cheesemaking traits. The dataset included records from 450 Holstein cows belonging to three dairy herds. After an initial screening (T0) to identify animals infected by Streptococcus agalactiae, Streptococcus uberis, Staphylococcus aureus, and Prototheca spp., 613 quarter milk samples for 2 different sampling times (T1 and T2, 1 mo after T1) were used for analysis. Milk traits were analyzed using a hierarchical linear mixed model including the effects of days in milk, parity and herd, and bacteriological and inflammatory category [culture negative with somatic cell count (SCC) $<200,000$ cells / $\mathrm{mL}$; culture negative with SCC $\geq 200,000$ cells/mL; or culture positive]. All udder health indicators were associated with increased SCC and IMI at both sampling times. The largest effects were detected at T2 for milk lactose $(-7 \%$ and $-5 \%)$ and milk conductivity $(+9 \%$ and $+8 \%)$. In contrast, the increase in differential SCC (DSCC) in samples with elevated SCC was larger at T1 $(+17 \%)$. Culture-negative samples with $\mathrm{SCC} \geq 200,000$ cells/mL had the highest SCC and greatest numbers of polymorphonuclear-neutrophils-lymphocytes and macrophages at both T1 and T2. Regarding milk cheesemaking ability, samples with elevated SCC showed the worst pattern of curd firmness at $\mathrm{T} 1$ and $\mathrm{T} 2$. At T2, increased SCC and IMI induced large decreases in recoveries of nutrients into the curd, in particular

Received September 10, 2021.

Accepted December 23, 2021.

*Corresponding author: sara.pegolo@unipd.it recovered protein $(-14 \%$ and $-16 \%)$ and recovered fat $(-12 \%$ and $-14 \%)$. Different behaviors were observed between Strep. agalactiae and Prototheca spp., especially at $\mathrm{T} 2$. In particular, samples that were positive for Strep. agalactiae had higher proportions of DSCC $(+19 \%)$ compared with negative samples with low SCC, whereas samples that were positive for Prototheca spp. had lower DSCC (-11\%). Intramammary infection with Prototheca spp. increased milk $\mathrm{pH}$ compared with culture-negative samples $(+3 \%)$ and negative samples that had increased SCC $(+2 \%)$. The greatest impairment in curd firmness at $30 \mathrm{~min}$ from rennet addition was observed for samples that were positive for Prototheca spp. ( $-99 \%$ compared with negative samples, and $-98 \%$ compared with negative samples with high SCC). These results suggest that IMI caused by Prototheca spp. have detrimental effects on milk technological traits that deserve further investigation of the mechanisms underlying animals' responses to infection.

Key words: subclinical mastitis, Staphylococcus aureus, Streptococcus agalactiae, Streptococcus uberis, Prototheca

\section{INTRODUCTION}

Mastitis has a major economic impact on the worldwide dairy industry. Increased costs attributed to mastitis include reduced milk production, increased veterinary treatments, culling of chronically infected cows, and occasional deaths (Seegers et al., 2003). Mastitis can be classified as either clinical or subclinical. Clinical mastitis is characterized by alterations of milk composition and appearance, decreased milk production, and the presence of the visible inflammation in 
infected mammary quarters. In cases of subclinical mastitis (SCM), no visible abnormalities of either the milk or the udder can be observed, and tests are required to detect the inflammatory responses that follows IMI (Abebe et al., 2016). Subclinical mastitis is more prevalent than the clinical form (Seegers et al., 2003). It is difficult to recognize and represents a major source of infection for other animals within the herd, causing significant losses in milk production (Ruegg, 2017).

Various microorganisms have been described as causative agents of mastitis in dairy cattle. Depending on region and farming system, contagious pathogens may include Streptococcus agalactiae, Staphylococcus aureus, and Mycoplasma bovis. Typical environmental pathogens include environmental streptococci (streptococci other than Strep. agalactiae such as Streptococcus uberis, Streptococcus dysgalactiae, and those belonging to genus Lactococcus and Enterococcus), Enterobacteriaceae, and CNS (NMC, 2017). Mastitis from yeastlike algae of the genus Prototheca has also become an emerging disease; its incidence is increasing despite its epidemiology being largely understudied (Jagielski et al., 2019). Moreover, as algae have innate resistance to antimicrobial treatments (Jagielski et al., 2017), IMI caused by Prototheca spp. represent an emerging threat to the dairy sector. There is a typical relationship between IMI caused by specific pathogens and the presentation of the disease. For instance, IMI caused by Strep. agalactiae and Prototheca spp. are typically associated with SCM (Bradley, 2002; Shave et al., 2021), whereas Staph. aureus often progresses to a clinical state (Wellnitz and Bruckmaier, 2012).

Increased SCC in milk is commonly used as indicator of SCM and reflects the onset of an immune response to the presence of IMI. The optimal SCC threshold to distinguish between infected and uninfected cows is often established at 200,000 cells/mL (International Dairy Federation, 2013). Recently, new diagnostic tools have been introduced that allow for differentiation among PMN and lymphocytes (LYM) versus macrophages (MAC). Combining differential somatic cell count (DSCC) and SCC information could help to define the stage of disease (high DSCC and SCC in the early stage of mastitis, low DSCC and high SCC in the cure phase; Damm et al., 2017). Previous studies report detrimental effects of IMI and inflammation on milk quality and composition (Bobbo et al., 2017; Pegolo et al., 2021) and cheesemaking traits (Le Maréchal et al., 2011; Bobbo et al., 2017; Pegolo et al., 2021). It is worth mentioning that a very low SCC was also reported to have a negative effect on some milk technological traits, which could be associated with an ineffective response to an undetectable mastitic event (Bobbo et al., 2016). Some authors also investigated these effects at the quarter level (Ogola et al., 2007; Malek dos Reis et al., 2013) with the aim of understanding relationships among mammary glands and clarifying immune mechanisms involved in the response to IMI. Moreover, Paixão et al. (2017) reported that a single quarter case of clinical mastitis influenced composition of milk from adjacent quarters, indicating the existence of an interdependency among mammary gland quarters.

In this context, differences in milk quality, composition, and cheesemaking traits among milk samples collected from healthy and subclinically-infected quarters have not yet been assessed in Holstein cows. In addition, the specific effects of IMI caused by Prototheca spp. have not been reported for these traits.

The aim of this study was to go beyond the standard screening based on SCC and use microbiological examination for detecting Strep. agalactiae, Staph. aureus, Strep. uberis, and Prototheca spp. IMI in all Holstein cows $(\mathrm{n}=450)$ belonging to 3 selected herds. Effects of naturally occurring SCM from these pathogens were assessed on milk composition, udder health indicators, and cheesemaking traits including milk coagulation properties (MCP), curd-firming (CF) traits, cheese yield $(\mathbf{C Y})$, and nutrient recovery in the curd (REC), using mammary quarters as experimental units.

\section{MATERIALS AND METHODS}

\section{Animals and Sampling}

This study was part of the LATSAN project, which aimed to develop innovative tools to study mammary gland health and improve nutritional quality and MCP in dairy cows. The research was approved by the Ethical Animal Care and Use Committee (OPBA - Organismo Preposto al Benessere degli Animali) of the Università Cattolica del Sacro Cuore and by the Italian Ministry of Health (protocol number 510/2019-PR of 19/07/2019).

The study was conducted using milk samples collected from 450 lactating Holstein cows kept in 3 commercial dairy farms located in the Veneto region (northern Italy; 144, 71, and 235 in herds A, B, and C, respectively). Herds were selected based on an initial survey carried out by the State Veterinary Laboratory for Northeastern Italy (IZSVe) to determine the herdprevalence of Strep. agalactiae, Staph. aureus, Strep. uberis, and Prototheca spp. in the Veneto region. Cows were housed in freestalls and fed TMR based mainly on corn silage, sorghum silage, and concentrates. Drinking water was available in automatic water bowls, and milking was carried out twice a day.

Animal health was managed by farmers and their local veterinarians, who observed animals and performed 
exams when needed. Because our goal was to evaluate subclinical cases, animals with clinical signs of mastitis as well as animals treated for mastitis were excluded from the trial. Information about enrolled cows (parity, DIM, milk yield, pregnancy status, animal health history) was obtained from herd management software (Dairy Comp Sata, v. 305, Alta Italia Srl).

\section{Experimental Design}

A longitudinal observational study was performed. Sampling was carried out at 3 periods selected on the pattern of inflammatory response (Sears et al., 1990; Rajala-Schultz et al., 1999). Milk samples were initially collected at time 0 (T0), when composite milk samples $(50 \mathrm{~mL})$ were aseptically taken from all lactating cows in each herd and used to identify healthy animals and IMI. Subsequently, quarter-milk samples were collected 2 (T1) and $6 \mathrm{wk}$ (T2) later (Figure 1). Milk sampling was performed following National Mastitis Council guidelines (NMC, 2017). Briefly, teat ends were cleaned externally with commercial pre-milking disinfectants by the veterinarian, dried with individual towels, and then cleaned again with alcohol. After discarding the first streams of foremilk, approximately $10 \mathrm{~mL}$ of milk from each quarter was collected in sterile tubes and pooled at T0. Milk samples were stored on ice until refrigerated at $4^{\circ} \mathrm{C}$.

Immediately after aseptic collection of milk samples for bacteriological analysis, approximately $150 \mathrm{~mL}$ of milk was manually collected from each cow (T0) or each quarter (T1 and T2) in a single container, divided into 3 subsamples, and maintained at $4^{\circ} \mathrm{C}$. Two $50-\mathrm{mL}$ subsamples without preservative were brought to the Milk Laboratory of the Department of Agronomy, Food, Natural Resources, Animals and Environment (DAF-
NAE) of the University of Padova (Italy) and processed within $24 \mathrm{~h}$ for the analysis of MCP and cheesemaking traits. One subsample $(50 \mathrm{~mL})$ with bronopol was transferred to the Milk Quality Laboratory of Breeders Association of Veneto Region (ARAV, Padova, Italy) for the analysis of milk composition. A representation of sampling scheme is displayed in Figure 1.

\section{Microbiological Analysis}

Microbiological analysis of composite and quartermilk samples was carried out at the State Veterinary Laboratory for Northeastern Italy (IZSVe). Samples were frozen after delivery to the laboratory and tested within $3 \mathrm{~d}$. We inoculated $10 \mu \mathrm{L}$ of milk from composite samples on each of the following selective media: BairdParker agar with rabbit plasma fibrinogen (Biokar Diagnostic), tallium kristalviolette tossin agar (IZSVe internal production), and Prothoteca isolation medium (IZSVe internal production). Baird-Parker agar with rabbit plasma fibrinogen plates were prepared according to standard 6888-2 (ISO, 1999), tallium kristalviolette tossin agar to the method described by Hauge and Ellingsen (1953), and Prothoteca isolation medium to National Mastitis Council guideline (NMC, 2017). Inoculated media were incubated at $37^{\circ} \mathrm{C}$. Baird-Parker agar base plates were observed for growth at 24 and $48 \mathrm{~h}$ of incubation. Suspected Staph. aureus colonies were confirmed by tube coagulase test (NMC, 2017). Thallium sulfate-crystal violet-B toxin blood agar plates were observed at $24 \mathrm{~h}$, and suspected colonies of Strep. agalactiae were confirmed using the ChristieAtkins-Munch-Peterson test (NMC, 2017). Prototheca isolation medium plates were observed at 24,48 , and 72 $\mathrm{h}$, and suspected colonies were confirmed by wet mount method (NMC, 2017).

\section{Bacteriological screening}

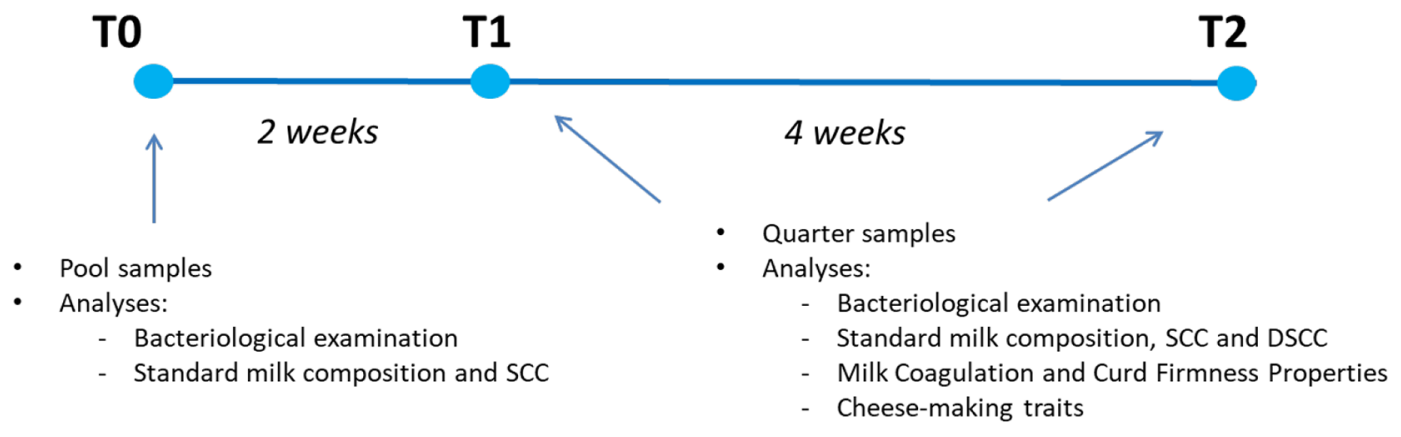

Figure 1. Representation of the sampling scheme. T0: sampling time 0 (bacteriological screening); T1: sampling time 1 (2 wk after T0); T2: sampling time 2 (4 wk after T1). DSCC: differential somatic cell count. 
Quarter-milk samples were cultured according to NMC guidelines (NMC, 2017). In brief, $10 \mu \mathrm{L}$ of milk was streaked on blood esculin agar; after incubation at $37^{\circ} \mathrm{C}$ for 16 to $18 \mathrm{~h}$, single isolated colonies were picked, subcultured, and identified using morphological examination, and a supplementary test was performed according to NMC (2017) guideline. Bacterial colonies with doubtful or inconsistent test results were identified by MALDI-TOF MS performed by Microflex Biotyper LT (Bruker Daltonics GmbH). A log (score) $\geq 2.0$ was the threshold used for the species level identification.

\section{Milk Composition and Quality Traits}

Analyses of milk quality and composition, including protein, casein, fat, and lactose percentages, urea $(\mathrm{mg} / 100 \mathrm{~g})$, and milk conductivity $(\mathrm{mS} / \mathrm{cm})$ were carried out with an FT6000 Milkoscan infrared analyzer (Foss A/S). Somatic cell counts (cells/mL) and DSCC were determined using a Fossomatic 7 DC analyzer (Foss A/S). To obtain a normal distribution, SCC was log-transformed to SCS (Ali and Shook, 1980). Two quantitative variables were derived from DSCC (proportion), which took into account the total SCC (Pegolo et al., 2021) as follows:

$$
\begin{aligned}
& \text { PMN-LYM count }=\text { DSCC } \times \operatorname{SCC}\left(10^{3} / \mathrm{mL}\right) \\
& \text { MAC count }=(1-\text { DSCC }) \times \operatorname{SCC}\left(10^{3} / \mathrm{mL}\right) .
\end{aligned}
$$

Similar to SCC, the PMN-LYM and MAC counts were then log-transformed as log2 (PMN-LYM or MAC count $/ 100,000)+3$ to achieve normality. Milk pH values were determined with a Crison Basic electrode (Crison Instruments SA).

\section{Analysis of Milk Coagulation and Curd Firmness Properties}

Analysis of MCP of milk was carried out in duplicate (to assess the repeatability of the analysis) by the same operator using 2 identical mechanical lactodynamographs (Formagraph; Foss A/S), according to Stocco et al. (2017). In brief, the procedure consisted of adding $200 \mu \mathrm{L}$ of rennet solution (Hansen Standard 215 with $80 \pm 5 \%$ chymosin and $20 \pm 5 \%$ pepsin; Pacovis Amrein $\mathrm{AG}$ ) diluted to $1.2 \%$ (wt/vol) with fresh distilled water to every milk sample $(10 \mathrm{~mL})$, previously heated in a water bath at $35^{\circ} \mathrm{C}$.

For each single-point MCP trait, we recorded rennet coagulation time (RCT; defined as the minutes from rennet addition to the start of coagulation), CF time $\left(\mathbf{k}_{\mathbf{2 0}}\right.$; defined as the minutes from rennet addition to reach a curd firmness of $20 \mathrm{~mm}$ ), and curd firmness $\left(\mathbf{a}_{\mathbf{3 0}} ; \mathrm{mm}\right)$ measured at $30 \mathrm{~min}$ after rennet addition. The 240 recordings of the width of the coagulation curve (1 every $15 \mathrm{~s}, 1$-h test length) extrapolated from the 2 Formagraph runs were modeled using the equation proposed by Bittante et al. (2013) to obtain estimates of the following $\mathrm{CF}$ and syneresis parameters: RCT, estimated from the curd-firming equation $\left(\mathbf{R C T}_{\mathbf{e q}}\right.$; $\min )$; the $\mathrm{CF}$ instant rate constant $\left(\mathbf{k}_{\mathbf{C F}} ; \%\right.$ min); the curd syneresis instant rate constant $\left(\mathbf{k}_{\mathrm{SR}} ; \% \mathrm{~min}\right)$; the maximum curve reached within $60 \mathrm{~min}\left(\mathbf{C F}_{\max } ; \mathrm{mm}\right)$; the asymptotic potential curd firmness $(\mathrm{mm})$; and time needed to reach $\mathrm{CF}_{\max }\left(\mathbf{t}_{\max } ; \min \right)$. Repeated observations were averaged before statistical analysis.

\section{Analysis of Cheesemaking Traits}

Cheese yield and nutrient recoveries were assessed in duplicate from milk samples using the 9-MilCA method proposed by Cipolat-Gotet et al. (2013). Briefly, $9 \mathrm{~mL}$ of each sample was poured into a glass tube and heated at $35^{\circ} \mathrm{C}$ for $15 \mathrm{~min}$ before adding $200 \mu \mathrm{L}$ of rennet solution (Hansen Standard 215 with $80 \pm 5 \%$ chymosin and $20 \pm 5 \%$ pepsin; Pacovis Amrein AG) diluted to $1.2 \%$ (wt/vol) with fresh distilled water, then incubated for $30 \mathrm{~min}$ at $35^{\circ} \mathrm{C}$. After incubation, a first cut was made manually with a stainless-steel spatula, then the samples were cooked at $55^{\circ} \mathrm{C}$ for 30 min with a further manual cut in the middle of the cooking phase. At the end of the cooking phase, each curd was separated from the whey for $30 \mathrm{~min}$ at room temperature, then gently pressed to accelerate whey drainage. The curd and whey were weighed separately with precision scales. Whey composition traits (fat, protein, lactose, and total solids) were determined with a MilkoScan FT-2 infrared spectrophotometer (Foss A/S). With this procedure, we obtained 7 cheesemaking-related traits. Three were related to cheese yield, representing the weight of curd $\left(\% \mathbf{C Y}_{\mathbf{C U R D}}\right)$, curd DM (\% $\left.\mathbf{C Y}_{\text {SOLIDS }}\right)$, and water retained in the curd $\left(\% \mathbf{C Y}_{\text {WATER }}\right)$ in percentage of the weight of milk processed. Four traits were related to nutrient recoveries in the curd as percentage of the same nutrient in the milk processed, representing recovered (REC) protein ( $\left.\mathbf{R E C}_{\text {PROTEIN }}\right)$, fat $\left(\mathbf{R E C}_{\mathbf{F A T}}\right)$, energy

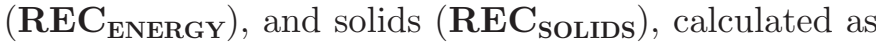
the differences in composition between curd and whey (Cipolat-Gotet et al., 2013). Repeated observations were averaged before statistical analysis.

\section{Statistical Analyses}

Initially, an exploratory data analysis was performed to check assumptions required for model fitting, hy- 
pothesis testing, and handling extreme values and making transformations of variables. Chi-squared analysis of the quarter frequencies was carried out to assess if subclinical IMI was associated with a specific quarter position $(P<0.05)$.

Associations between subclinical IMI and milk composition (fat, protein, casein, and urea), udder health indicators (SCS, DSCC, log PMN-LYM count, log MAC count, lactose, casein index, $\mathrm{pH}$ and conductivity), and cheesemaking traits (MCP, CF, CY, and REC traits) were investigated using linear mixed models in PROC MIXED (SAS Institute Inc.). Sampling times (T1 and T2) were analyzed independently because of heterogeneity of variances. In our study, we considered the single mammary quarter as the experimental unit. The hierarchical model was as follows:

$$
\begin{gathered}
\mathrm{y}_{i j k l m n}=\mu+\mathrm{DIM}_{i}+\text { parity }_{j}+\operatorname{herd}_{k}+\mathrm{BACT}_{l} \\
+\mathrm{R}_{m: i j k}+\mathrm{e}_{i j k l m n},
\end{gathered}
$$

where $\mathrm{y}_{i j k l m n}$ is the investigated phenotype previously defined at the quarter level; $\mu$ is the overall mean; DIM $_{i}$ is the fixed effect of the $i$ th class of days in milk $(i=3$ classes; class $1 \leq 120 ; 120<$ class $2 \leq 240$; class $3>$ $240) ;$ parity $_{j}$ is the fixed effect of the $j$ th parity $(j=$ primiparous; multiparous); $\operatorname{herd}_{k}$ is the fixed effect of the $k$ th herd ( $k=3$ herds); $\mathrm{BACT}_{l}$ is the fixed effect of the $l$ th bacteriological status $(l=3$ classes; neg $=$ negative at bacteriological examination, SCC $<200,000$ cells $/ \mathrm{mL}$; negHSCC $=$ negative at bacteriological examination, $\mathrm{SCC} \geq 200,000$ cells $/ \mathrm{mL}$; pos $=$ positive at bacteriological examination for any pathogen); $\mathrm{R}_{m: i j k}$ is the random effect of the $m$ th replicate (animal) nested within $\operatorname{DIM}_{i}$, parity ${ }_{j}$, and herd ${ }_{k}$; and $\mathrm{e}_{i j k l m n}$ is the random residual. We assumed $\mathrm{R}$ and residuals were normally distributed with a mean of zero and variances of $\sigma_{r}^{2}$ and $\sigma_{e}^{2}$, respectively. With this nested design, the effects of $\operatorname{DIM}_{i}$, parity $_{j}$, and herd ${ }_{k}$ were tested on the error line of $m$ th animal nested within $\operatorname{DIM}_{i}$, parity ${ }_{j}$, and herd ${ }_{k}$, whereas the $\mathrm{BACT}_{l}$ effect as well as animal were tested on the residual term. The effect of the number of affected quarters was also tested. It was significant with none of the traits; therefore, it was excluded from the final analyses. To account for multiple testing, we applied Bonferroni correction with significance at 0.05 .

A second level of analyses was carried out to evaluate potential effects of IMI caused by Strep. agalactiae and Prototheca spp. To this aim, we focused on herd C, which showed higher prevalence of subclinical IMI from both pathogens. Cases of co-infection were excluded before statistical analyses.

The hierarchical model was as follows:

$$
\mathrm{y}_{i j k l m}=\mu+\mathrm{DIM}_{i}+\text { parity }_{j}+\mathrm{BACT}_{k}+\mathrm{R}_{l: i j}+\mathrm{e}_{i j k l m},
$$

where $y_{i j k l m}$ is the investigated phenotype; $\mu$ is the overall mean; DIM $_{i}$ is the fixed effect of the $i$ th class of days in milk ( $i=3$ classes; class $1 \leq 120 ; 120<$ class $2 \leq 240$; class $3>240$ ); parity $_{j}$ is the fixed effect of the $j$ th parity ( $j=$ primiparous; multiparous); $\mathrm{BACT}_{k}$ is the fixed effect of the $k$ th bacteriological status $(l=$ 4 classes; neg $=$ negative at bacteriological examination, $\mathrm{SCC}<200,000$ cells $/ \mathrm{mL}$; negHSCC $=$ negative at bacteriological examination, SCC $\geq 200,000$ cells/ $\mathrm{mL} ; \mathrm{Sa}+=$ positive for Strep. agalactiae, and $\mathrm{P}+=$ positive for Prototheca); $\mathrm{R}_{l: i j}$ is the random effect of the lth replicate (animal) nested within $\mathrm{DIM}_{i}$ and parity ${ }_{j}$. As previously defined, the effects of DIM $i$, and parity $_{j}$ were tested on the error line of $l$ th animal nested within $\mathrm{DIM} i$, and parity $j$, whereas the $\mathrm{BACT}_{k}$ effect as well as animal were tested on the residual term. To account for multiple testing, we applied Bonferroni correction with a significance of 0.05 .

\section{RESULTS}

\section{Characteristics of Cows and Microbiological Analyses}

In all herds, most cows were in their second or greater parity (Table 1). In herd A, most cows were in early or late lactation, whereas most were in mid-late lactation in herds B and C (Table 1). Overall, average milk production was similar among herds, whereas SCC was much lower in herd $\mathrm{B}$ with respect to herds $\mathrm{A}$ and $\mathrm{C}$ (Table 1). Of 450 cows, 78 were positive at bacteriological examination (T0) and were followed up at the quarter level at $\mathrm{T} 1$ and $\mathrm{T} 2$. Isolated microorganisms were Staph. aureus ( $\mathrm{n}=6$ animals from 2 herds), Strep. agalactiae ( $\mathrm{n}=51$ animals from 2 herds), Prototheca spp. ( $\mathrm{n}=19$ animals from 1 herd), and Strep. uberis ( $\mathrm{n}$ $=5$ from 1 herd; Table 2). Three animals from 1 herd had co-infection of Strep. agalactiae and Prototheca spp. No differences were detected in milk production and milk composition between cows negative and positive at bacteriological examination, except for SCS and DSCC, which were higher in the latter group of animals $(P<0.001$; Table 3).

The number of quarter-milk samples were 321 at T1 and 292 at T2. Samples contaminated from environmental microorganisms were 19 and 11 at $\mathrm{T} 1$ and T2, respectively, and were excluded before the statistical analysis. The most prevalent pathogen was Strep. agalactiae at both $\mathrm{T} 1(\mathrm{n}=50,15.6 \%)$ and $\mathrm{T} 2(\mathrm{n}=38$, $13 \%$ ). At T1, 3 quarter samples were positive for both 
Table 1. Herd descriptive data ( \pm values represent SD)

\begin{tabular}{lcccc}
\hline Item & Herd A & Herd B & Herd C & Overall data \\
\hline Number of Cows & 144 & 71 & 235 & 450 \\
DIM (n) & & & & \\
Class $1 \leq 120$ & 61 & 10 & 40 & 111 \\
$>120$ Class $2 \leq 240$ & 34 & 28 & 109 & 186 \\
Class 3 240 & 49 & 24 & & 129 \\
Parity (n) & 45 & 45 & 175 & 321 \\
$\quad$ Primiparous & 99 & $30.54 \pm 8.83$ & $31.47 \pm 10.80$ & $30.72 \pm 9.84$ \\
Multiparous & $32.25 \pm 7.61$ & $75.49 \pm 210.72$ & $390.57 \pm 671.27$ & $280.27 \pm 581.12$ \\
Milk yield, kg/d & & & \\
SCC $\times 10^{3}$ cells $/ \mathrm{mL}$ & $202.69 \pm 506.27$ & & & \\
\hline
\end{tabular}

Strep. agalactiae and Prototheca spp. At T2, 2 quarter samples were positive for both Strep. agalactiae and Prototheca spp., and one quarter sample was positive for both Strep. agalactiae and Staph. aureus. Among animals positive at bacteriological examination, at $\mathrm{T} 1$, $20(42 \%)$ had 1 infected quarter, $14(29 \%)$ had 2 infected quarters, $6(13 \%)$ had 3 infected quarters, and $8(17 \%)$ had 4 infected quarters. Similarly, at T2, $17(53 \%)$ had 1 infected quarter, $12(38 \%)$ had 2 infected quarters, and $3(9 \%)$ had 3 infected quarters. No significant associations between quarter position and SCM was found $(P>$ $0.05)$ as evaluated by chi-squared analysis of the quarter frequencies of each pathogen (Supplemental Table S1, https://figshare.com/articles/dataset/Supplementary _Table_S1_Quarter_frequencies_of_each_pathogen _identified_by_microbiological_culture_/19102490).

\section{Association of IMI with Quarter-Level Milk Composition and Udder Health Indicators}

Milk Composition. Bacteriological status was associated with the concentration milk urea at T1 and T2 $(P<0.001)$, and milk fat $(P<0.001)$ and protein $(P$ $<0.01$ ) proportion at T2 (Table 4 ). At T1, high SCC $(\geq 200,000$ cells $/ \mathrm{mL})$ decreased milk urea by about $5 \%$. At T2, high SCC and subclinical IMI decreased milk urea $(-5 \%$ and $-7 \%$, respectively) and increased milk fat proportion $(+24 \%$ and $+13 \%$, respectively) and milk protein proportion $(+2 \%$; Figure 2$)$.
Udder Health Indicators. Bacteriological status was associated with all traits at both $\mathrm{T} 1$ and $\mathrm{T} 2(P$ $<0.01$ ). In addition, larger $\mathrm{F}$ values were observed at T2 for all traits except for proportion of DSCC (Table 4). At T1, higher concentration of somatic cells and presence of IMI were associated with decreased milk lactose $(-5 \%$ and $-3 \%)$ and casein index $(-1 \%)$, and with increased milk conductivity $(+8 \%$ and $+5 \%)$. Elevated SCC were associated with increased milk $\mathrm{pH}$ $(+1 \%)$ and DSCC (+17\%; Figure 2). At T2, increased SCC and IMI were associated with reduced milk lactose $(-7 \%$ and $-5 \%)$ and casein index $(-1 \%)$, and increased milk conductivity $(+9 \%$ and $+8 \%)$ and milk $\mathrm{pH}(+1 \%$; Figure 3). The DSCC increased as SCC increased $(+10 \%)$. At both T1 and T2, culture-negative samples with SCC $\geq 200,000$ cells $/ \mathrm{mL}$ and positive samples had higher SCS, log PMN-LYM count, and log MAC count as compared with culture-negative samples (Figure 3).

Associations of IMI with Quarter-Level Cheesemaking Traits. Bacteriological status was associated with milk cheesemaking traits at both $\mathrm{T} 1$ and T2 $(P<0.01)$, except for $\% \mathrm{CY}_{\text {Solids }}$ at T1 (Table 5$)$. At T1, increased SCC was associated with increased RCT $(+33 \%)$ and $\mathrm{k}_{20}(+28 \%)$, and with decreased $\mathrm{a}_{30}(-53 \%)$ with respect to culture-negative samples with SCC $<200,000$ cells $/ \mathrm{mL}$. At T2, increased SCC was associated with increased RCT $(+18 \%)$. The SCC and subclinical IMI increased $\mathrm{k}_{20}(+27 \%$ and $+17 \%$, respectively) and decreased $\mathrm{a}_{30}(-48 \%$ and $-37 \%$,

Table 2. Microbiological results of milk samples collected at the different sampling times ${ }^{1}$

\begin{tabular}{|c|c|c|c|c|c|c|}
\hline \multirow[b]{2}{*}{ Microbiological result } & \multicolumn{2}{|c|}{ T0 } & \multicolumn{2}{|c|}{$\mathrm{T} 1$} & \multicolumn{2}{|c|}{$\mathrm{T} 2$} \\
\hline & $\mathrm{N}$ & $\%$ & $\mathrm{~N}$ & $\%$ & $\mathrm{~N}$ & $\%$ \\
\hline Staphylococcus aureus & 6 & 1.3 & 4 & 1.2 & 3 & 1.0 \\
\hline Streptococcus agalactiae & 51 & 11.3 & 50 & 15.6 & 38 & 13.0 \\
\hline Prototheca spp. & 19 & 4.2 & 17 & 5.3 & 11 & 3.8 \\
\hline Streptococcus uberis & 5 & 1.1 & 3 & 0.9 & 1 & 0.3 \\
\hline Contaminated samples & 0 & 0 & 19 & 5.9 & 11 & 3.8 \\
\hline
\end{tabular}

${ }^{1}$ T0: time 0 , pool samples; T1: time 1, 2 wk after time 0, quarter samples; T2: time 2, 4 wk after T1, quarter samples. 
Table 3. Milk yield and standard composition of cows testing negative or positive at the bacteriological screening (T0)

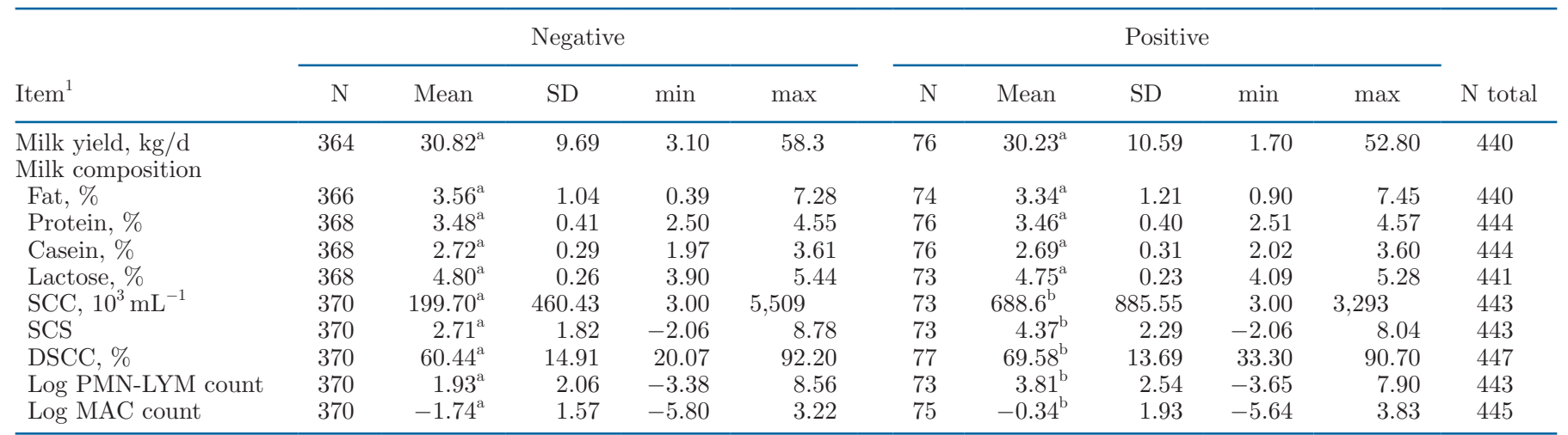

${ }^{\mathrm{a}, \mathrm{b}}$ Different letters indicate significant differences between groups (Welch's $t$-test, $P<0.001$ ).

${ }^{1} \mathrm{SCS}=$ somatic cell score expressed as $\log 2(\mathrm{SCC} / 100)+3 ; \mathrm{DSCC}=$ differential somatic cell count; $\operatorname{logPMN-LYM~count~}=$ polymorphonuclear neutrophils-lymphocytes count expressed as log2 [(PMN-LYM count $) / 100,000]+3 ; \log$ MAC count $=$ macrophages count expressed as log2 (MAC count $/ 100,000)+3$.

respectively; Table 5). Culture-negative samples with SCC $\geq 200,000$ cells/mL had the least favorable pattern of curd firmness at T1 and T2 (Figure 4).

At T1, elevated SCC were associated with increased $\% \mathrm{CY}_{\mathrm{CURD}}(+8 \%)$ and $\% \mathrm{CY}_{\text {WATER }}(+10 \%)$, and decreased $\mathrm{REC}_{\mathrm{FAT}}(-4 \%), \mathrm{REC}_{\mathrm{SOLIDS}}(-9 \%)$, and $\mathrm{RE}-$ $\mathrm{C}_{\text {ENERGY }}(-12 \%)$. Elevated SCC and subclinical IMI were associated with decreased $\mathrm{REC}_{\text {PROTEIN }}(-15 \%$ and $-12 \%$, respectively). At T2, elevated SCC were associated with increased $\% \mathrm{CY}_{\mathrm{CURD}}$ and $\% \mathrm{CY}_{\text {WATER }}$ with respect to negative and positive samples $(+7 \%$ and $+9 \%$, respectively). Elevated SCC and subclinical IMI were associated with decreased $\% \mathrm{CY}_{\text {SOLIDS }}(-13 \%$ and
$-20 \%$, respectively), $\mathrm{REC}_{\text {Protein }}(-14 \%$ and $-16 \%$, respectively), $\operatorname{REC}_{\mathrm{FAT}}(-12 \%$ and $-14 \%$, respectively), $\mathrm{REC}_{\text {SOLIDS }}(-9 \%$ and $-12 \%$, respectively), and $\mathrm{RE}-$ $\mathrm{C}_{\text {ENERGY }}(-13 \%$; Figure 5$)$.

Associations of IMI with Strep. agalactiae and Prototheca spp. on Quarter-Level Milk Composition, Udder Health, and Milk Technological Traits. At T1, a pathogen-specific effect was detected for $\mathrm{k}_{\mathrm{CF}}$ and $\mathrm{k}_{\mathrm{SR}}$. When compared with milk that was culture negative and had low SCC, milk from quarters infected with Strep. agalactiae had decreased $\mathrm{k}_{\mathrm{CF}}(-32 \%)$ and $\mathrm{k}_{\mathrm{SR}}(-40 \%)$, whereas infection with Prototheca spp. was not associated with any changes in

Table 4. Results from ANOVA ( $F$-value and significance) for quarter-level milk composition, and udder health at sampling time 1 (T1) and 2 (T2)

\begin{tabular}{|c|c|c|c|c|c|c|c|c|}
\hline Item $^{1}$ & \multicolumn{4}{|c|}{$\mathrm{T} 1$} & \multicolumn{4}{|c|}{$\mathrm{T} 2$} \\
\hline \multicolumn{9}{|l|}{ Milk composition } \\
\hline Protein, \% & $15.96^{* * *}$ & 1.60 & 0.17 & 0.32 & $12.68^{* * *}$ & $<0.01$ & 0.48 & $6.69^{* *}$ \\
\hline Casein, $\%$ & $15.04^{* * *}$ & 1.64 & 0.44 & 2.76 & $11.06^{* * *}$ & 0.05 & 0.18 & 1.75 \\
\hline Urea, mg/100 g & $4.96^{* *}$ & $<0.01$ & $16.61^{* * *}$ & $4.92^{* *}$ & $6.63^{* *}$ & 0.06 & 1.92 & $11.52^{* * *}$ \\
\hline \multicolumn{9}{|l|}{ Udder health } \\
\hline DSCC, $\%$ & 1.99 & 2.67 & 2.30 & $9.37 * * *$ & 2.91 & 3.64 & 1.91 & $4.99^{* *}$ \\
\hline Log PMN-LYM count & $9.20^{* * *}$ & 0.58 & $13.18^{* * *}$ & $63.72^{* * *}$ & $6.42^{* *}$ & 0.77 & $16.28^{* * *}$ & $103.92^{* * *}$ \\
\hline Log MAC count & $13.97 * * *$ & 0.74 & $15.61^{* * *}$ & $59.24^{* * *}$ & $5.46^{* *}$ & 0.22 & $13.50^{* * *}$ & $111.97^{* * *}$ \\
\hline Lactose, $\%$ & 3.09 & 2.34 & 1.04 & $17.55^{* * *}$ & $4.21^{*}$ & 0.08 & 0.49 & $42.29^{* * *}$ \\
\hline Casein index, \% & 1.26 & 0.54 & 1.78 & $7.76^{* * *}$ & 3.11 & $6.58^{*}$ & $5.64^{* *}$ & $23.05^{* * *}$ \\
\hline $\mathrm{pH}$ & 0.42 & 1.40 & $11.20^{* * *}$ & $6.29 * *$ & 0.56 & 0.02 & 2.24 & $9.30^{* * *}$ \\
\hline Milk conductivity, $\mathrm{mS} / \mathrm{cm}$ & 0.39 & 1.44 & 0.54 & $12.56^{* * *}$ & 0.91 & 0.67 & 0.64 & $27.25^{* * *}$ \\
\hline
\end{tabular}

${ }^{1}$ Casein index $=($ casein $/$ protein $) \times 100 ;$ SCS $=$ somatic cell score expressed as log2 $(\mathrm{SCC} / 100)+3 ;$ DSCC = differential somatic cell count; $\log$ PMN-LYM count $=$ polymorphonuclear neutrophils-lymphocytes count expressed as $\log 2[(\mathrm{PMN}-\mathrm{LYM}$ count $) / 100,000]+3 ; \log \mathrm{MAC}$ count $=$ macrophages count expressed as $\log 2(\mathrm{MAC}$ count/100,000 $)+3$.

${ }^{2} \mathrm{BACT}$ classes defined as follows: negative at bacteriological examination, SCC $<200,000(0)$; negative at bacteriological examination, SCC $\geq$ 200,000 cells $/ \mathrm{mL}$ (1); and positive at bacteriological examination (2).

${ }^{*} P<0.05 ;{ }^{* *} P<0.01 ;{ }^{* * *} P<0.001$. 

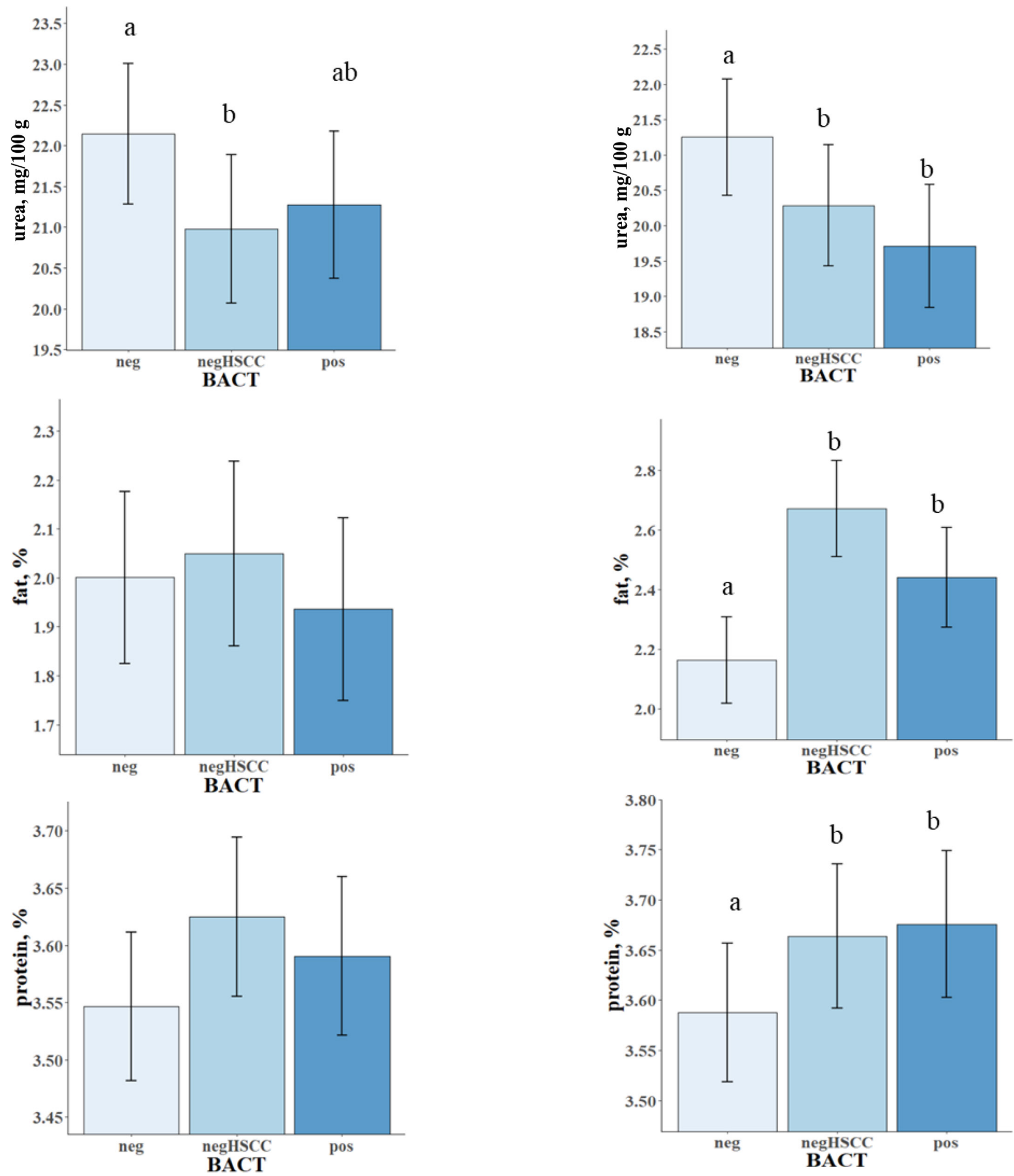

Figure 2. Least squares means of milk composition according to bacteriological (BACT) status classes. Only significant traits at (left) time 1 and (right) time 2 were displayed. BACT classes were defined as follows: negative at bacteriological examination and SCC $<200,000$ cells/ $\mathrm{mL}$ (neg); negative at bacteriological examination and SCC $\geq 200,000$ cells/mL (negHSCC); and positive at bacteriological examination (pos). Different letters $(\mathrm{a}, \mathrm{b})$ indicate significant differences between groups (Bonferroni correction, $P<0.05)$. Error bars represent SEM. 
the traits (Table 6 and Figure 6). Culture-negative milk with increased SCC and milk from quarters infected with Strep. agalactiae were associated with similar changes in $\mathrm{k}_{\mathrm{CF}}$ and $\mathrm{k}_{\mathrm{SR}}$. In contrast, milk from quarters infected with Prototheca spp. had higher $\mathrm{k}_{\mathrm{CF}}$ and $\mathrm{k}_{\mathrm{SR}}$ as compared with culture-negative milk that had increased SCC $(+56 \%$ and $+103 \%$, respectively).

At T2, milk from quarters infected with Strep. agalactiae had higher DSCC proportion $(+19 \%)$ when compared with culture-negative milk from quarters with low SCC, whereas milk from quarters infected with Prototheca spp. had lower $(-11 \%)$ DSCC. Prototheca spp. infection was associated with increased milk $\mathrm{pH}$ as compared with culture-negative milk $(+3 \%)$ and as compared with culture-negative milk that contained increased SCC $(+2 \%)$. Conversely, milk from quarters with IMI caused by Strep. agalactiae had decreased $\mathrm{pH}$ when compared with culture-negative milk from a) $\mathrm{T1}$
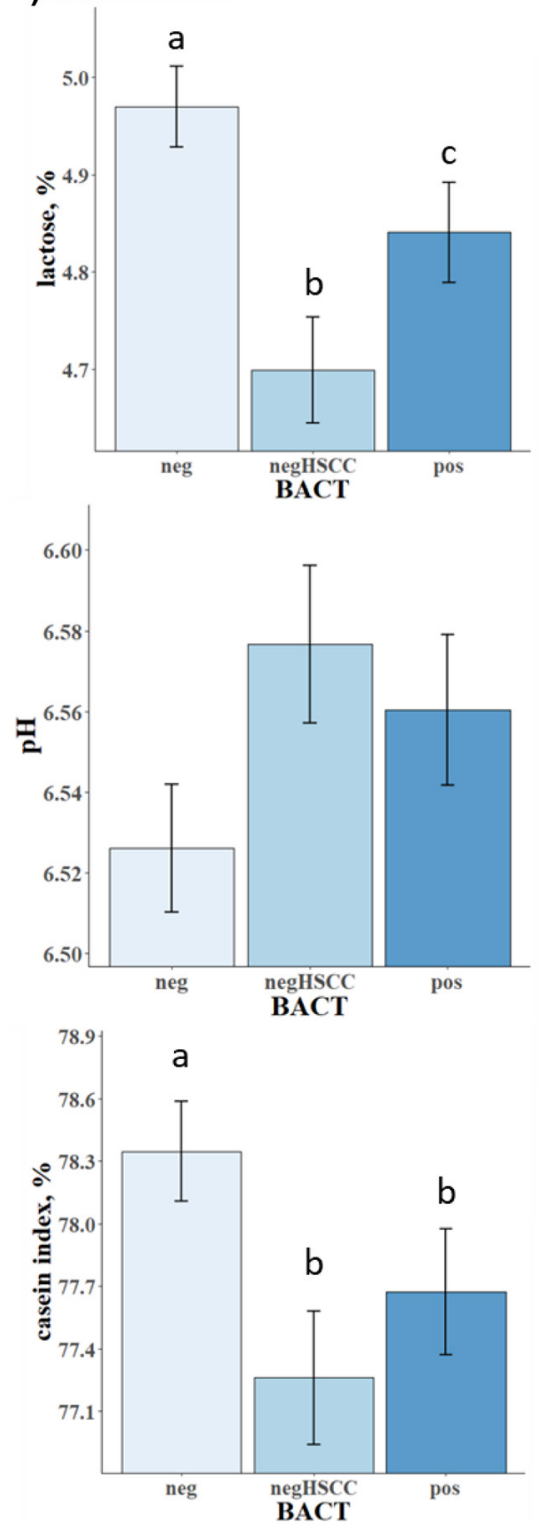

b) T2
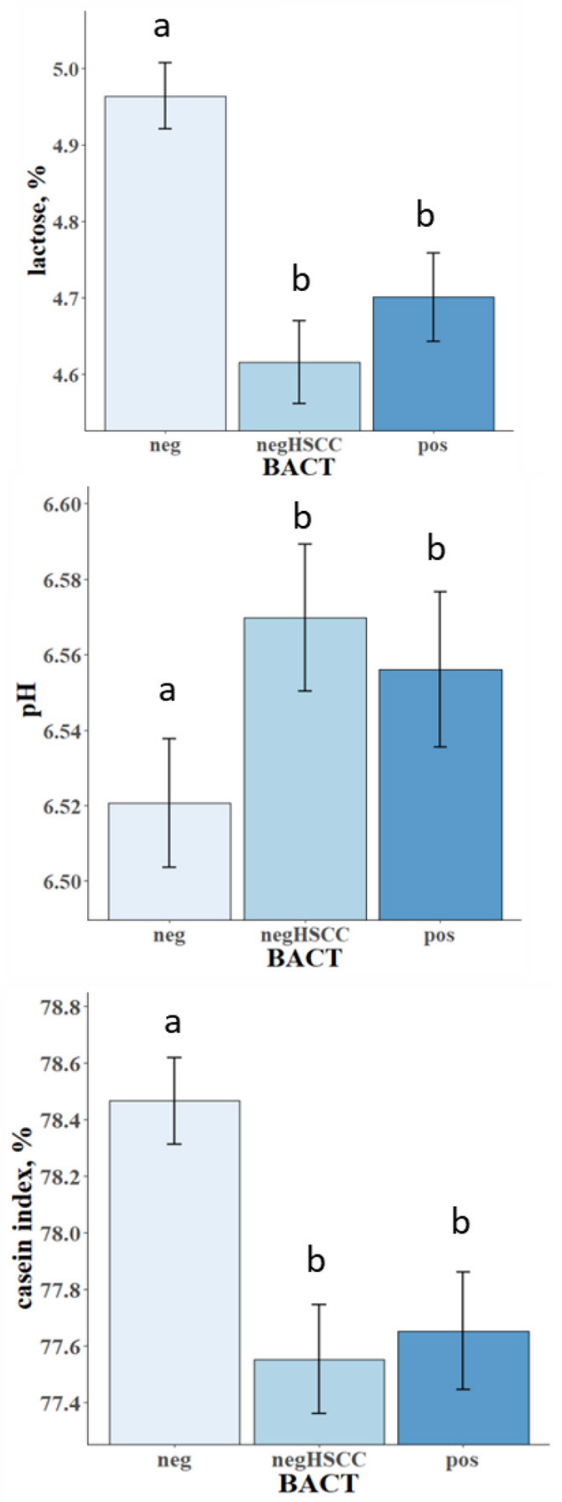

Figure 3. Least squares means of udder health traits according to bacteriological (BACT) status classes. Only significant traits at (left) time 1 and (right) time 2 were displayed. BACT classes were defined as follows: negative at bacteriological examination and SCC <200,000 cells/ $\mathrm{mL}$ (neg); negative at bacteriological examination and SCC $\geq 200,000$ cells/mL (negHSCC); and positive at bacteriological examination (pos). DSCC: differential somatic cell count; log PMN-LYM count: polymorphonuclear neutrophils-lymphocytes count expressed as log2 [(PMN-LYM count $) / 100,000]+3$; $\log$ MAC count: macrophages count expressed as log2 (macrophage count $/ 100,000)+3 ;$ casein index $=($ casein $/$ protein $) \times$ 100. Different letters $(\mathrm{a}-\mathrm{c})$ indicate significant differences between groups (Bonferroni correction, $P<0.05$ ). Error bars represent SEM. 
inflamed quarters $(-1 \%)$. The greatest impairment in $\mathrm{a}_{30}$ was observed in the case of Prototheca spp. infection ( $-99 \%$ when compared with milk from culture-negative quarters and $-98 \%$ respect to negative samples with high SCC). Similarly, IMI caused by Prototheca spp. had the worst effects on CF parameters as well as on REC traits. In comparison with culture-negative milk and culture-negative milk with increased SCC, culturepositive milk had lower potential curd firmness $(-72 \%$ and $-59 \%$, respectively), $\mathrm{k}_{\mathrm{CF}}(-76 \%$ and $-71 \%$, re- a) $\mathrm{T} 1$

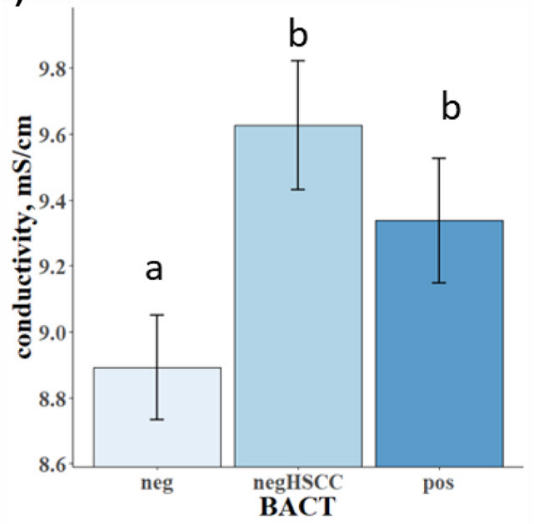

b
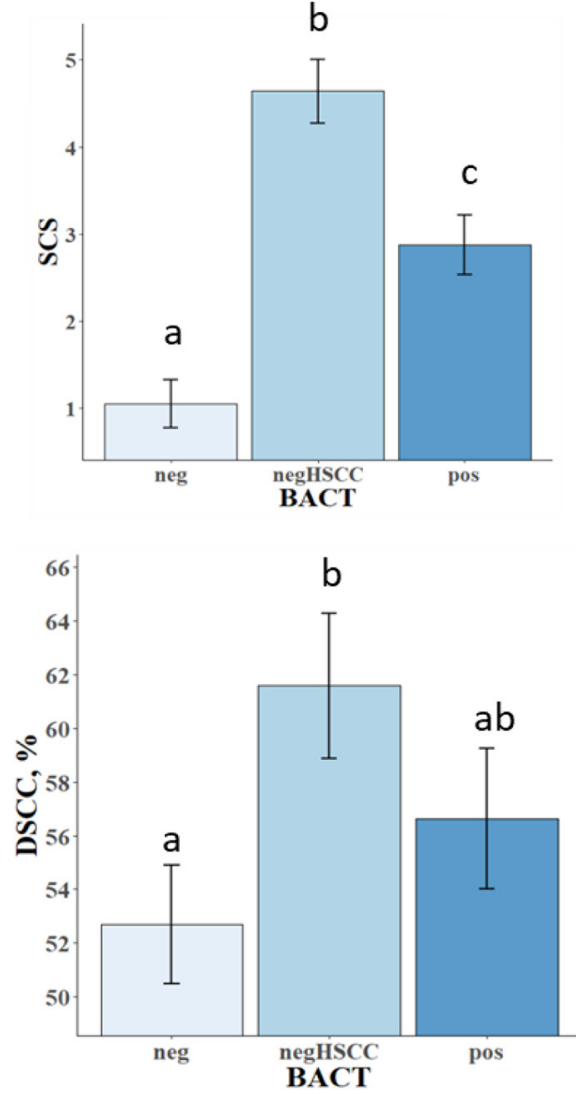

\section{b) T2}
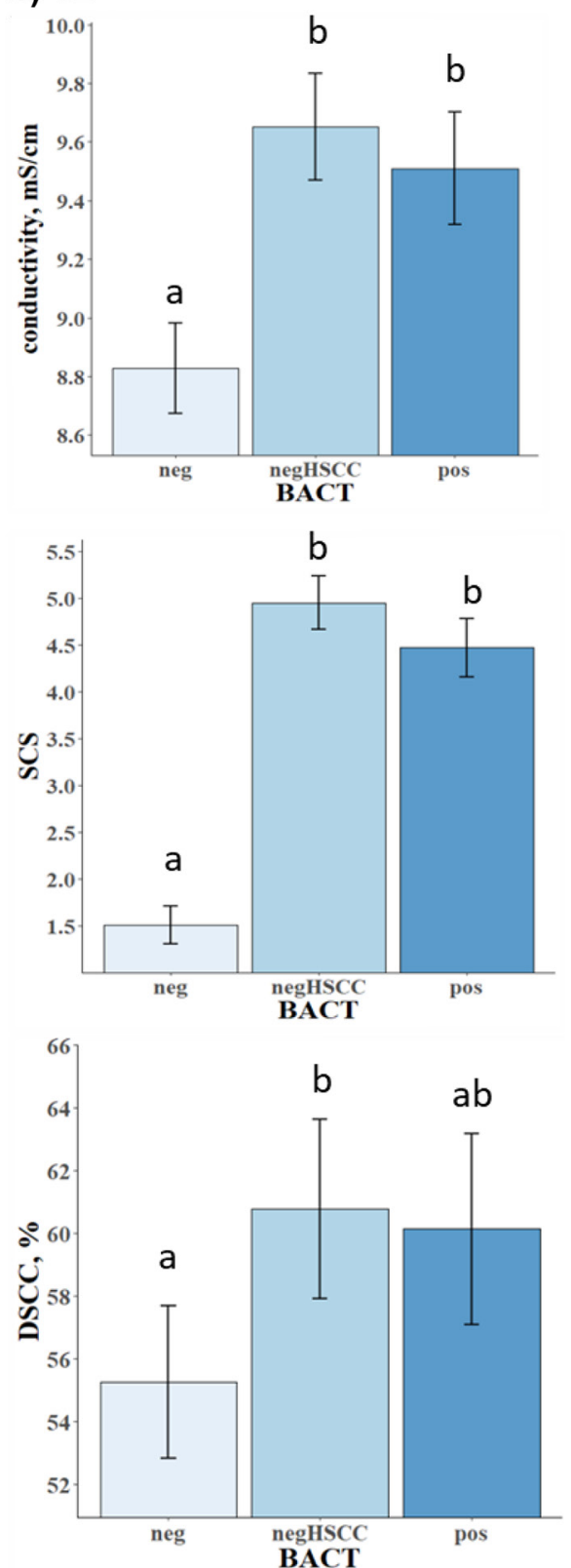

Figure 3 (Continued). Least squares means of udder health traits according to bacteriological (BACT) status classes. Only significant traits at (left) time 1 and (right) time 2 were displayed. BACT classes were defined as follows: negative at bacteriological examination and SCC $<200,000$ cells $/ \mathrm{mL}$ (neg); negative at bacteriological examination and SCC $\geq 200,000$ cells/mL (negHSCC); and positive at bacteriological examination (pos). DSCC: differential somatic cell count; log PMN-LYM count: polymorphonuclear neutrophils-lymphocytes count expressed as $\log 2[(\mathrm{PMN}-\mathrm{LYM}$ count $) / 100,000]+3$; log MAC count: macrophages count expressed as log2 (macrophage count/100,000) + 3; casein index $=($ casein $/$ protein $) \times 100$. Different letters $(\mathrm{a}-\mathrm{c})$ indicate significant differences between groups (Bonferroni correction, $P<0.05)$. Error bars represent SEM. 
spectively), $\mathrm{k}_{\mathrm{SR}}(-99 \%)$ and $\mathrm{CF}_{\max }(-72 \%$ and $-59 \%$, respectively), $\operatorname{REC}_{\text {PROTEIN }}(47 \%$ and $40 \%$ respectively), and $\mathrm{REC}_{\mathrm{FAT}}(-39 \%$ and $-35 \%$; Table 6 and Figure 6$)$.

\section{DISCUSSION}

In this study, we investigated quarter-level associations of SCM with milk composition, udder health indicators, and milk technological characteristics in Holstein cows. The effects of mastitis in dairy cattle have generally evaluated composite milk and thus could be influenced by dilution related to the number of infected quarters. In the present study, subclinical IMI mostly affected 1 or 2 quarters, which is in accordance with previous data in the literature (Salat et al., 2008). From a preliminary analysis, the number of affected quarters was not associated with any of the traits we evaluated (data not shown).

a) $\mathrm{T} 1$
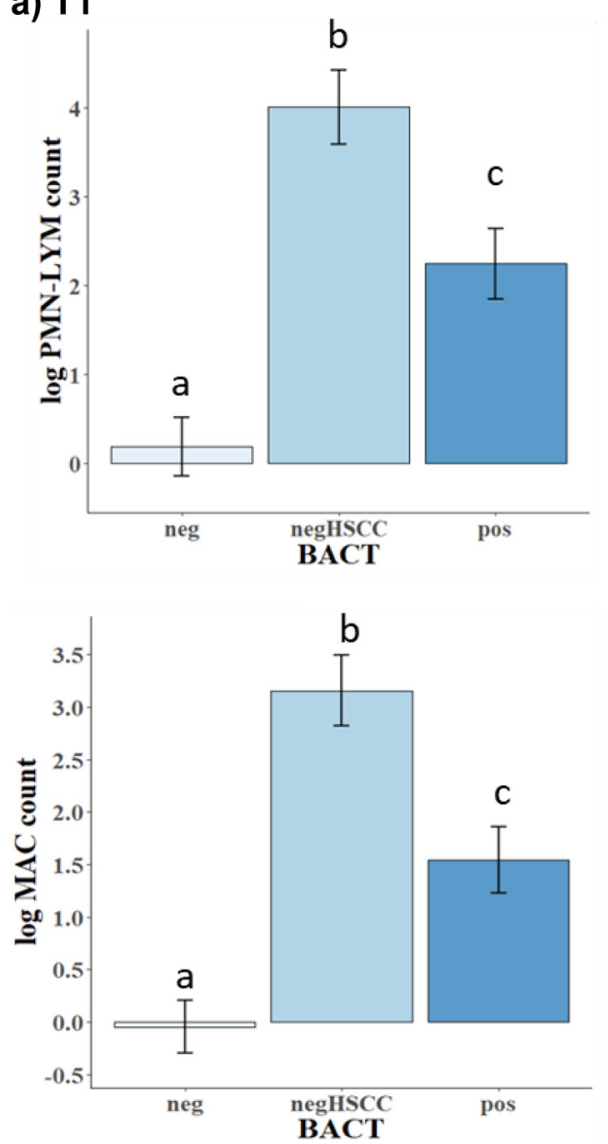

Compositional changes of milk due to IMI reflect the extent of the degree and stage of inflammation. Detrimental effects of IMI on milk composition, udder health, and cheesemaking traits were greater at T2 (4 wk after T1), which may be explained by a possible increase in the magnitude of inflammation (Paixão et al., 2017) with a progression of the subclinical disease toward the clinical form or a shift to chronic mastitis. This hypothesis might be supported by the increase in SCS observed at T2 as compared with T1.

We observed that culture-negative milk containing increased SCC was characterized by impaired milk composition and cheesemaking ability, which demonstrated that bacteriological results and the inflammatory status were not always consistent (i.e., risk of false negative samples; Bobbo et al., 2017). The presence of IMI and increased SCC were associated with several composition and udder health traits. The lower lactose propor-

\section{b) T2}
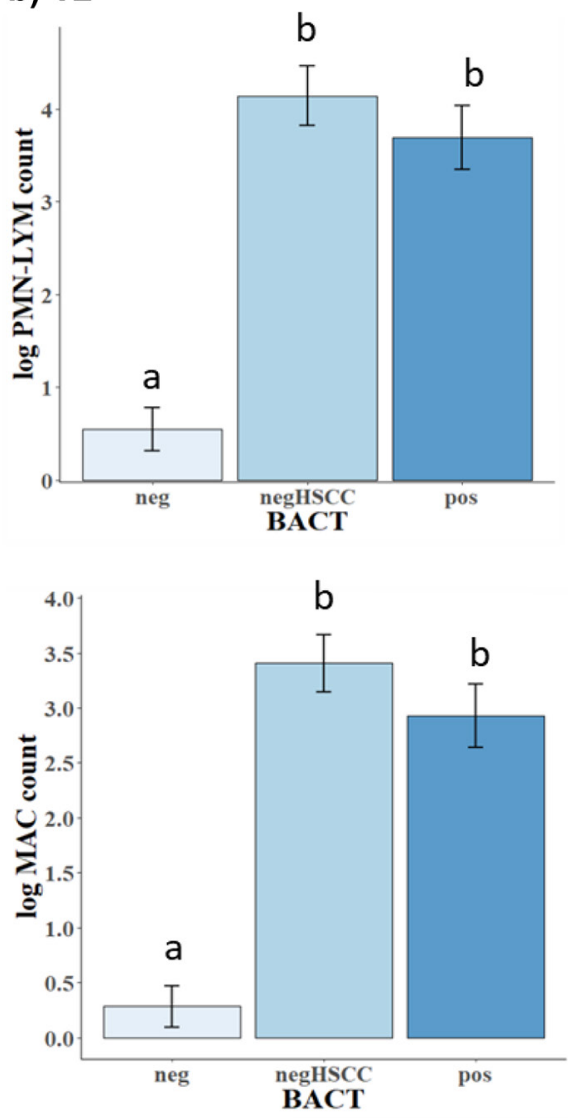

Figure 3 (Continued). Least squares means of udder health traits according to bacteriological (BACT) status classes. Only significant traits at (left) time 1 and (right) time 2 were displayed. BACT classes were defined as follows: negative at bacteriological examination and SCC $<200,000$ cells/mL (neg); negative at bacteriological examination and SCC $\geq 200,000$ cells/mL (negHSCC); and positive at bacteriological examination (pos). DSCC: differential somatic cell count; log PMN-LYM count: polymorphonuclear neutrophils-lymphocytes count expressed as $\log 2[($ PMN-LYM count) $/ 100,000]+3 ; \log$ MAC count: macrophages count expressed as $\log 2$ (macrophage count/100,000) + 3; casein index $=($ casein $/$ protein $) \times 100$. Different letters $(\mathrm{a}-\mathrm{c})$ indicate significant differences between groups (Bonferroni correction, $P<0.05)$. Error bars represent SEM. 
Table 5. Results from ANOVA ( $F$-value and significance) for quarter-level traditional milk coagulation properties (MCP), curd-firming (CF) properties, cheese yields (\%CY), and curd nutrient recoveries (REC) at sampling time 1 (T1) and 2 (T2)

\begin{tabular}{|c|c|c|c|c|c|c|c|c|}
\hline Item $^{1}$ & \multicolumn{4}{|c|}{$\mathrm{T} 1$} & \multicolumn{4}{|c|}{$\mathrm{T} 2$} \\
\hline $\mathrm{RCT}, \min$ & 1.54 & 0.22 & $4.33^{*}$ & $16.71^{* * *}$ & 2.00 & 0.28 & $3.71^{*}$ & $10.51^{* * *}$ \\
\hline $\mathrm{k}_{20}, \min$ & 0.57 & 0.67 & 1.90 & $7.29^{* * *}$ & 0.60 & 0.18 & 2.08 & $11.33^{* * *}$ \\
\hline $\mathrm{a}_{30}, \mathrm{~mm}$ & 0.10 & 0.07 & 1.42 & $21.11^{* * *}$ & 0.94 & 0.06 & $3.29^{*}$ & $15.98^{* * *}$ \\
\hline \multicolumn{9}{|l|}{ Curd firming } \\
\hline $\mathrm{k}_{\mathrm{CF}}, \% \times \min ^{-1}$ & 0.39 & 0.09 & 2.36 & $7.28^{* * *}$ & 1.66 & 0.15 & 0.60 & $5.89^{* *}$ \\
\hline $\mathrm{k}_{\mathrm{SR}}, \% \times \min ^{-1}$ & 0.24 & 0.17 & $3.39^{*}$ & $12.28^{* * *}$ & $3.22 *$ & 0.22 & 0.24 & $11.93^{* * *}$ \\
\hline $\mathrm{CF}_{\max }, \mathrm{mm}$ & 0.31 & 0.10 & 0.18 & $17.11^{* * *}$ & 2.70 & $<0.01$ & $4.25^{*}$ & $23.18^{* * *}$ \\
\hline $\mathrm{t}_{\max }, \min$ & 1.22 & 0.03 & 2.97 & $6.36^{* *}$ & $4.09^{*}$ & $<0.01$ & 1.29 & $3.57^{*}$ \\
\hline \multicolumn{9}{|l|}{ Cheese yields, $\%$} \\
\hline$\% \mathrm{CY}_{\mathrm{CURD}}$ & 0.19 & 0.31 & 3.23 & $7.51^{* * *}$ & $6.95^{* *}$ & 0.65 & 0.37 & $5.02^{* *}$ \\
\hline$\% \mathrm{CY}_{\text {SOLIDS }}$ & $5.26^{* *}$ & 0.43 & 1.05 & 1.17 & $8.54^{* * *}$ & 0.06 & 2.54 & $6.25^{* *}$ \\
\hline $\mathrm{REC}_{\text {ENERGY }}$ & 1.24 & 0.06 & 0.30 & $6.55^{* *}$ & 1.11 & 0.04 & 0.73 & $7.77^{* * *}$ \\
\hline
\end{tabular}

${ }^{1} \mathrm{RCT}=$ rennet coagulation time; $\mathrm{k}_{20}=$ curd-firming rate as the time to a curd firmness of $20 \mathrm{~mm} ; \mathrm{a}_{30}=$ curd firmness at 30 min from rennet addition; $\mathrm{RCT}_{\mathrm{eq}}=$ rennet coagulation time estimated using the equation; $\mathrm{CF}_{\mathrm{P}}=$ asymptotic potential curd firmness; $\mathrm{k}_{\mathrm{CF}}=$ curd-firming instant rate constant; $\mathrm{k}_{\mathrm{SR}}=$ syneresis instant rate constant; $\mathrm{CF}_{\max }=$ maximum curd firmness achieved within 45 min; $\mathrm{t}_{\max }=$ time at achievement of $\mathrm{CF}_{\max } ; \% \mathrm{CY}_{\mathrm{CURD}}=$ weight of fresh curd as percentage of weight of milk processed; $\% \mathrm{CY}_{\text {SOLIDS }}=$ weight of curd solids as percentage of weight of milk processed; $\% \mathrm{CY}_{\text {WATER }}=$ weight of water curd as percentage of weight of milk processed; $\mathrm{REC}_{\mathrm{PROTEIN}}=$ protein of the curd as percentage

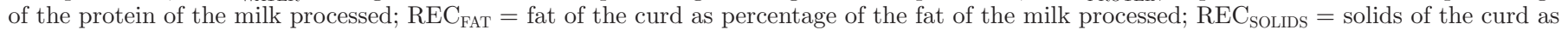
percentage of the solids of the milk processed; $\mathrm{REC}_{\mathrm{ENERGY}}=$ energy of the curd as percentage of energy of the milk processed.

${ }^{2}$ BACT classes defined as follows: negative at bacteriological examination, SCC $<200,000(0)$; negative at bacteriological examination, SCC $\geq$ 200,000 cells $/ \mathrm{mL}(1)$; and positive at bacteriological examination (2).

${ }^{*} P<0.05 ;{ }^{* *} P<0.01 ;{ }^{* * *} P<0.001$.

tion observed in culture-positive quarters is caused by the reduced secretory activities of the mammary cells and increased permeability of the mammary epithelium (Malek dos Reis et al., 2013; Pegolo et al., 2021). The decrease in casein index is linked to increased endogenous proteolysis due to increased plasmin or other proteases derived from somatic cells, which can explain the greater effect observed in negative samples with
A

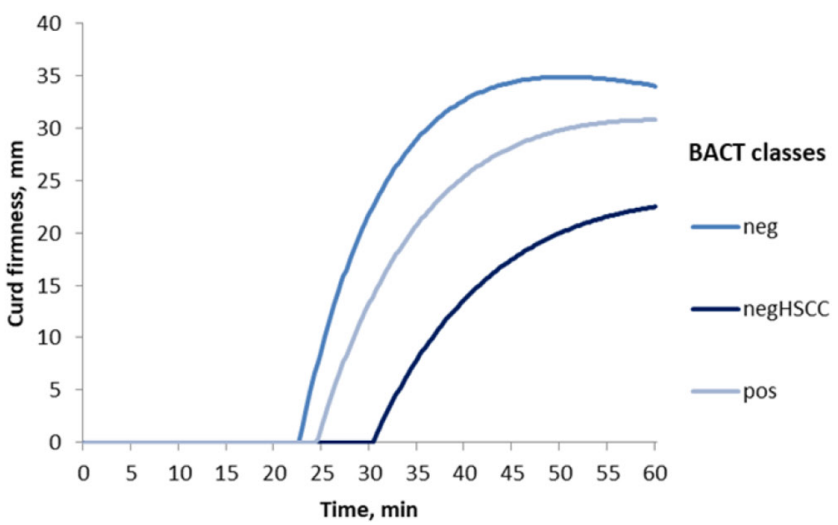

B

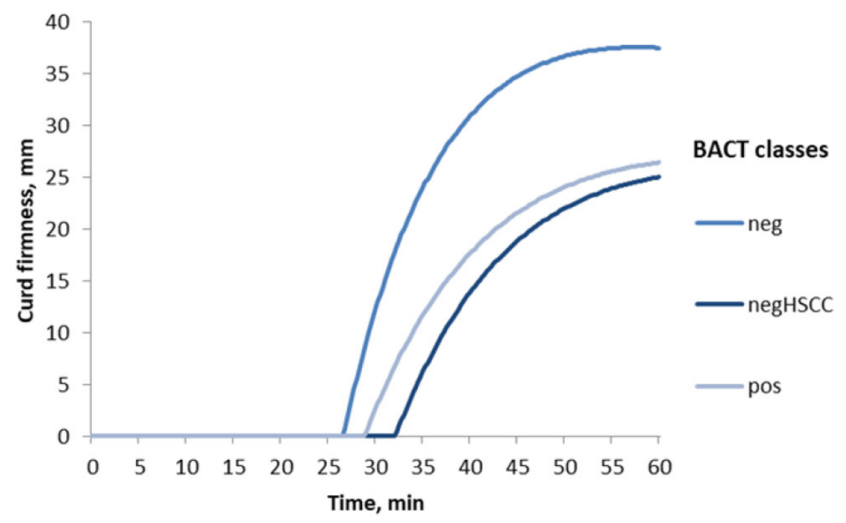

Figure 4. Pattern of curd firmness after rennet addition of milk samples according to bacteriological (BACT) status classes at (A) time 1 and (B) time 2. BACT classes were defined as follows: negative at bacteriological examination and SCC $<200,000 \mathrm{cells} / \mathrm{mL}$ (neg); negative at bacteriological examination and SCC $\geq 200,000$ cells/mL (negHSCC); and positive at bacteriological examination (pos). 
high SCC. This condition leads to the breakdown of casein and the influx of blood proteins (immunoglobulins, IgG, and BSA) into milk for the increased permeability of mammary epithelium, which results in an elevated noncasein nitrogen and whey protein content (Ogola et al., 2007). Milk conductivity is considered an indicator of udder health as a result of changes in the ion balance associated with the inflammatory response to IMI. We observed an increase in milk conductivity in quarter samples with elevated SCC and affected by subclinical IMI, which is explained by the increase in milk concentration of $\mathrm{Na}^{+}$and $\mathrm{Cl}^{-}$(Norberg, 2005). As a) T1
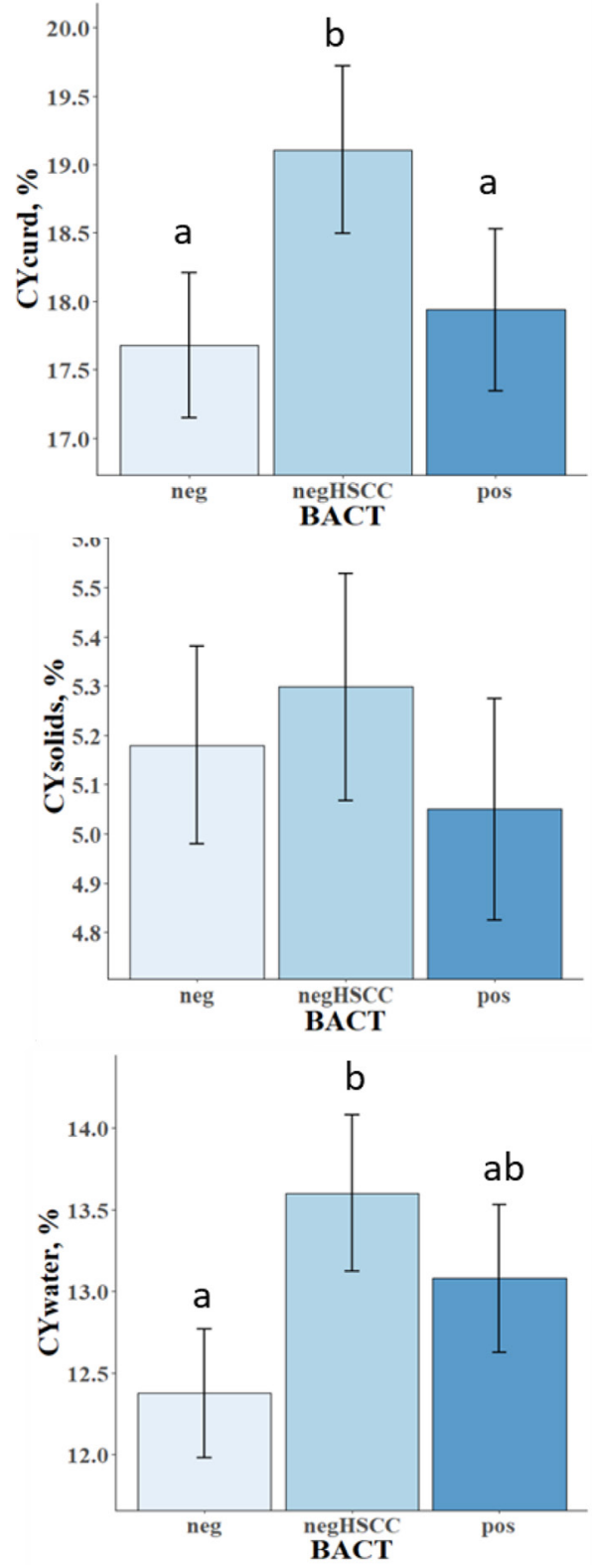

b) T2
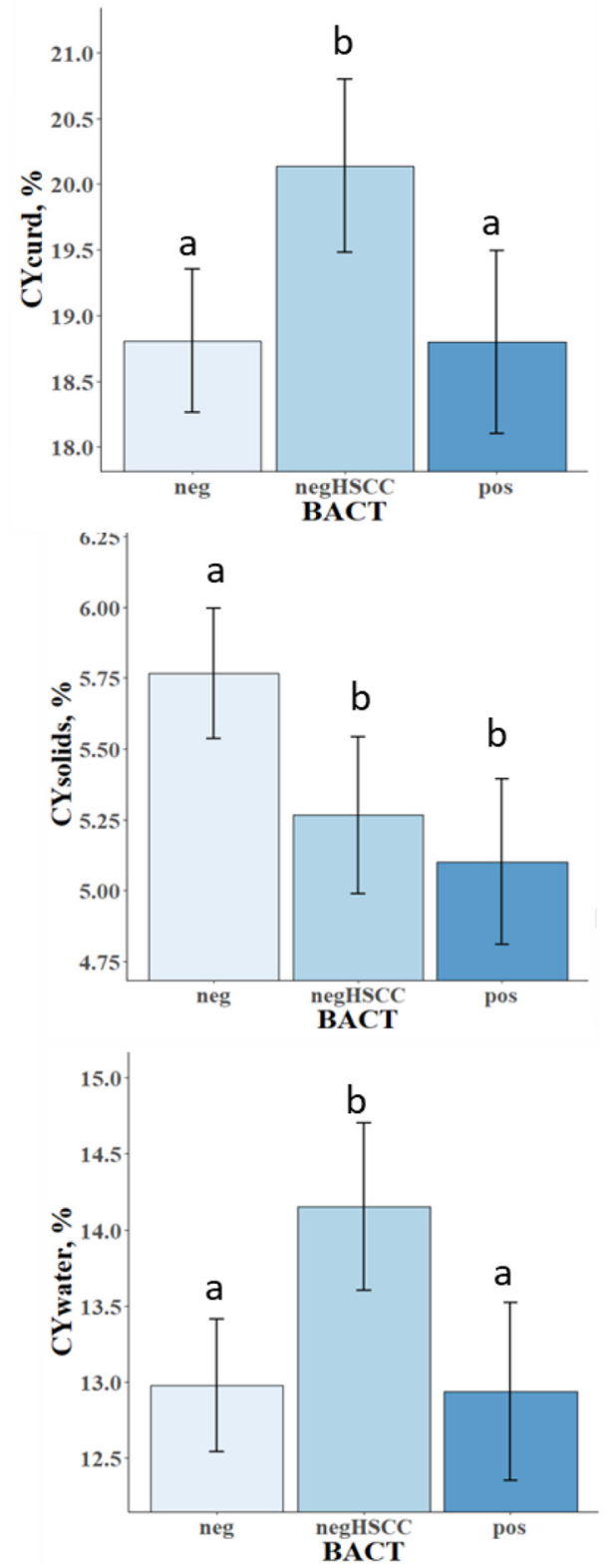

Figure 5. Least squares means of cheesemaking traits according to bacteriological (BACT) status classes (negative and positive). Only significant traits at (left) time 1 and (right) time 2 were displayed. BACT classes were defined as follows: negative at bacteriological examination and SCC $<200,000$ cells $/ \mathrm{mL}$ (neg); negative at bacteriological examination and SCC $\geq 200,000$ cells/mL (negHSCC); and positive at bacteriological examination (pos). CYcurd = weight of fresh curd as percentage of weight of milk processed; CYsolids = weight of curd solids as percentage of weight of milk processed; CYwater = weight of water curd as percentage of weight of milk processed; RECprotein $=$ protein of the curd as percentage of the protein of the milk processed; RECfat $=$ fat of the curd as percentage of the fat of the milk processed; RECsolids $=$ solids of the curd as percentage of the solids of the milk processed; RECenergy = energy of the curd as percentage of energy of the milk processed. Different letters (a,b) indicate significant differences between groups (Bonferroni correction, $P<0.05$ ). Error bars represent SEM. 
a) T1
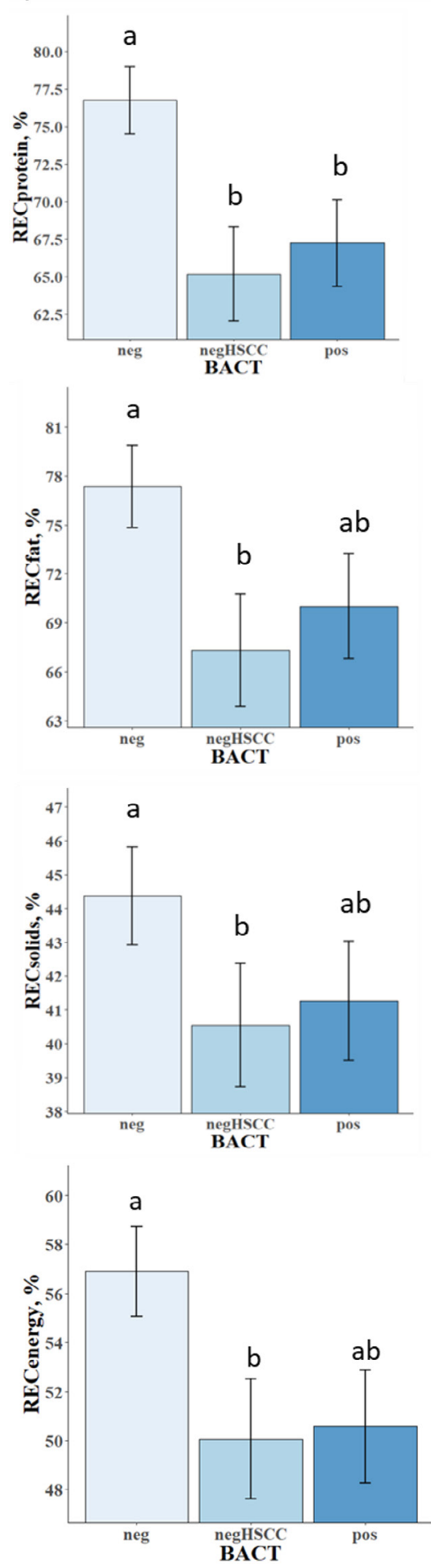

b) T2
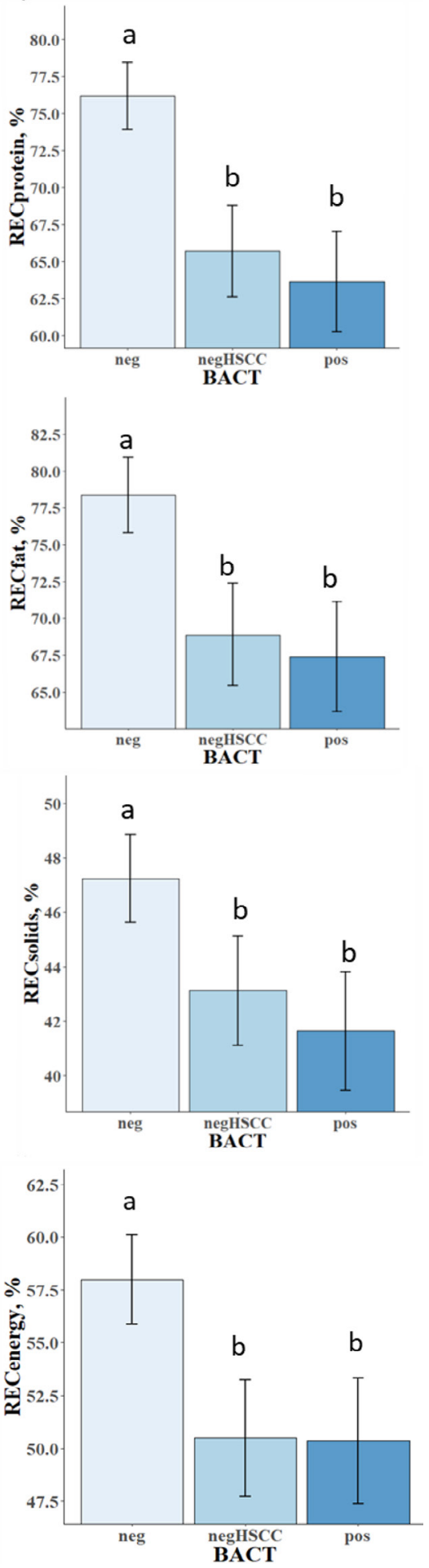

Figure 5 (Continued). Least squares means of cheesemaking traits according to bacteriological (BACT) status classes (negative and positive). Only significant traits at (left) time 1 and (right) time 2 were displayed. BACT classes were defined as follows: negative at bacteriological examination and SCC $<200,000$ cells/mL (neg); negative at bacteriological examination and SCC $\geq 200,000$ cells/mL (negHSCC); and positive at bacteriological examination (pos). CYcurd $=$ weight of fresh curd as percentage of weight of milk processed; CYsolids $=$ weight of curd solids as percentage of weight of milk processed; CYwater $=$ weight of water curd as percentage of weight of milk processed; RECprotein $=$ protein of the curd as percentage of the protein of the milk processed; RECfat = fat of the curd as percentage of the fat of the milk processed; RECsolids $=$ solids of the curd as percentage of the solids of the milk processed; RECenergy = energy of the curd as percentage of energy of the milk processed. Different letters (a,b) indicate significant differences between groups (Bonferroni correction, $P<0.05$ ). Error bars represent SEM. 
a consequence of the difference between the concentration of the main strong cations and anions (Kandeel et al., 2019), milk pH also increased.

The increase in SCC seemed to be mostly due to the increase in PMN-LYM (both as proportions and as count). The relative proportions of the various leukocyte populations mirrored the mammary gland health status. In healthy udders, the main cell types are LYM and MAC (Dosogne et al., 2003; Schwarz et al., 2011). In case of acute inflammatory condition, the increase in SCC is mainly due to the migration of PMN that are essential components of the innate immunity (Sarikaya et al., 2006), whereas in chronic condition, the proportion of MAC increase in milk with high SCC (Leitner et al., 2000). Differential SCC include both PMN and LYM populations; differentiation of cell populations

Table 6. Results from ANOVA (LSM, F-value and significance) for quarter-level milk composition, and udder health at sampling time 1 (T1) and 2 (T2) for herd $\mathrm{C}^{1}$

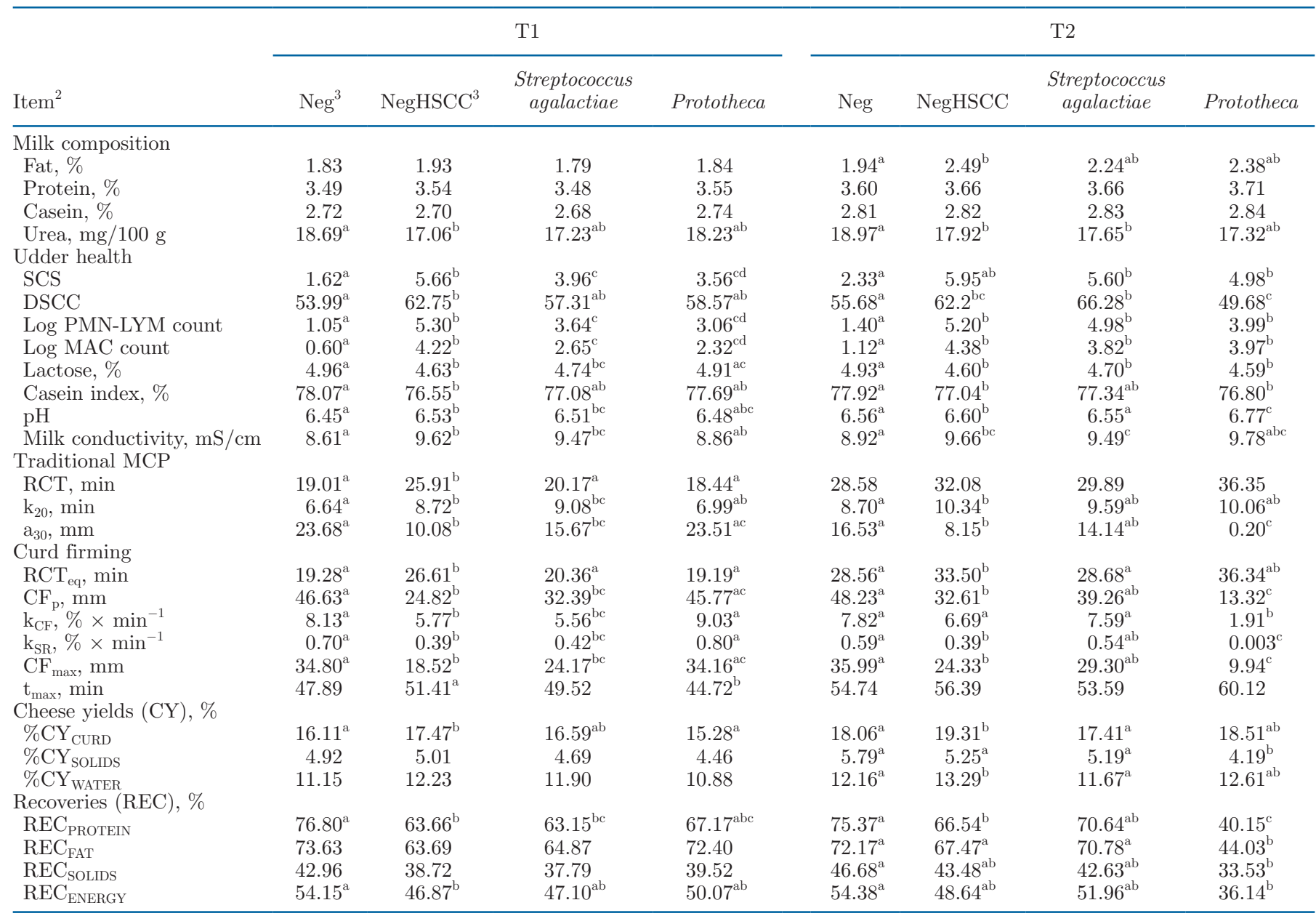

${ }^{\mathrm{a}-\mathrm{c}}$ Different letters indicate significant differences between groups (Bonferroni correction, $P<0.05$ ).

${ }^{1}$ Herd C was selected for the second-level analyses (Strep. agalactiae vs. Prototheca).

${ }^{2}$ Casein index $=($ casein $/$ protein $) \times 100 \mathrm{SCS}=$ somatic cell score expressed as $\log 2(\mathrm{SCC} / 100)+3 ;$ DSCC $=$ differential somatic cell count; $\log$ PMN-LYM count $=$ polymorphonuclear neutrophils-lymphocytes count expressed as log2 [(PMN-LYM count $) / 100,000]+3 ; \log M A C$ count $=$ macrophages count expressed as $\log 2(\mathrm{MAC}$ count $/ 100,000)+3 ; \mathrm{MCP}=$ milk coagulation properties; $\mathrm{RCT}=$ rennet coagulation time; $\mathrm{k}_{20}$ $=$ curd-firming rate as the time to a curd firmness of $20 \mathrm{~mm} ; \mathrm{a}_{30}=$ curd firmness at $30 \mathrm{~min}$ from rennet addition; $\mathrm{RCT}_{\mathrm{eq}}=\mathrm{rennet}_{\mathrm{B}}$ coagulation time estimated using the equation; $\mathrm{CF}_{\mathrm{P}}=$ asymptotic potential curd firmness; $\mathrm{k}_{\mathrm{CF}}=$ curd-firming instant rate constant; $\mathrm{k}_{\mathrm{SR}}=$ syneresis instant rate constant; $\mathrm{CF}_{\max }=$ maximum curd firmness achieved within $45 \mathrm{~min} ; \mathrm{t}_{\max }=$ time at achievement of $\mathrm{CF}_{\max } ; \%_{\mathrm{CY}} \mathrm{CURD}=$ weight of fresh curd as percentage of weight of milk processed; $\% \mathrm{CY}_{\mathrm{SOLIDS}}=$ weight of curd solids as percentage of weight of milk processed; $\% \mathrm{CY}$ WATER $=$ weight of water curd as percentage of weight of milk processed; $\mathrm{REC}_{\text {PRотеIN }}=$ protein of the curd as percentage of the protein of the milk processed; $\mathrm{REC}_{\mathrm{FAT}}=$ fat of the curd as percentage of the fat of the milk processed; $\mathrm{REC}_{\mathrm{SOLIDS}}=$ solids of the curd as percentage of the solids of the milk processed; $\mathrm{REC}_{\mathrm{ENERGY}}=$ energy of the curd as percentage of energy of the milk processed.

${ }^{3} \mathrm{Neg}=$ negative at bacteriological examination and SCC $<200,000$ cells $/ \mathrm{mL}$; negHSCC = negative at bacteriological examination and SCC $\geq 200,000$ cells $/ \mathrm{mL}$; Strep. agalactiae $=$ positive at bacteriological examination for Strep agalactiae; Prototheca = positive at bacteriological examination for Prototheca spp. 
by flow cytometry would allow identification of which leukocyte populations are mostly responsible for the increase in SCC and for the changes in SCC composition observed in case of subclinical IMI.

Increased SCC and IMI strongly affected milk technological traits in accordance with previous findings (Le Maréchal et al., 2011; Bobbo et al., 2017). Modification of the relative contents of protein fractions (decrease in casein proportion) has a relevant effect on the technological behavior of bovine milk (Le Roux et al., 2003; Amalfitano et al., 2019). Milk coagulation process starts with hydrolysis of $\kappa$-CN by the chymosin of rennet followed by the aggregation of casein micelles, which form a reticulum entrapping the soluble phase and fat globules (Guinee, 2003). The number of secondary interactions within the curd increases over time, leading to its contraction (syneresis) and partial expulsion of whey. The increase in proteases released by leukocytes can explain why the worst effects on curd firmness pattern were detected in case of elevated SCC.

Contrasting results have been reported in literature regarding the specific effects of pathogen-specific subclinical IMI. Akerstedt et al. (2012) found that IMI caused by Strep. agalactiae was associated with milk protein degradation in vitro. The comparison of infected and uninfected quarters in Gyr cows evidenced that subclinical IMI caused by Streptococcus spp. was associated with a reduced milk fat, nonfat solids, and total solids proportions but not with a reduced protein proportion (Malek dos Reis et al., 2013). Other researchers did not find any difference in fat, protein, and casein proportions following pathogen-specific natural infection (Bobbo et al., 2017). This might be related to the time from the beginning of inflammation, method of analyses (in vitro or natural infection), and sampling (pool or quarters). Furthermore, different breeds could have differences in the homeostatic control or in microbiota interactions within the mammary gland (Cremonesi et al., 2018; Curone et al., 2018). Conversely, the effects of SCM from Prototheca spp. infection on milk composition have never been evaluated as well as the specific effects of Strep. agalactiae and Prototheca spp. on milk technological characteristics.

Streptococcus agalactiae and Prototheca spp. seemed to have a different influence on some milk traits. Both pathogens were associated with an increased SCS in affected quarters; however, the population of inflammatory responses as measured by DSCC proportion diverged. These results supported that bovine Prototheca mastitis seemed to induce a leukocyte response mostly shifted toward MAC (rather than PMN) and agree with previous research (Wawron et al., 2013). Prototheca spp. induced an increase in milk $\mathrm{pH}$, which is subsequent to alteration in the mineral equilibrium between milk and blood; the presence of LPS-like molecules in the cell wall of Prototheca spp. might induce a higher damage to the blood-milk barrier (Irrgang et al., 2015).

Prototheca spp. were associated with more detrimental effects on MCP and cheesemaking traits as compared with Strep. agalactiae, which can be only partially explained by observed alterations in milk composition and quality (higher $\mathrm{pH}$ and slightly lower casein index in the case of Prototheca spp. infection) and deserve further investigation. The characterization of individual leukocyte subpopulations in milk samples from affected and healthy animals could provide useful information that could help explain the differential effects of the 2 pathogens on milk quality and cheesemaking traits.
A

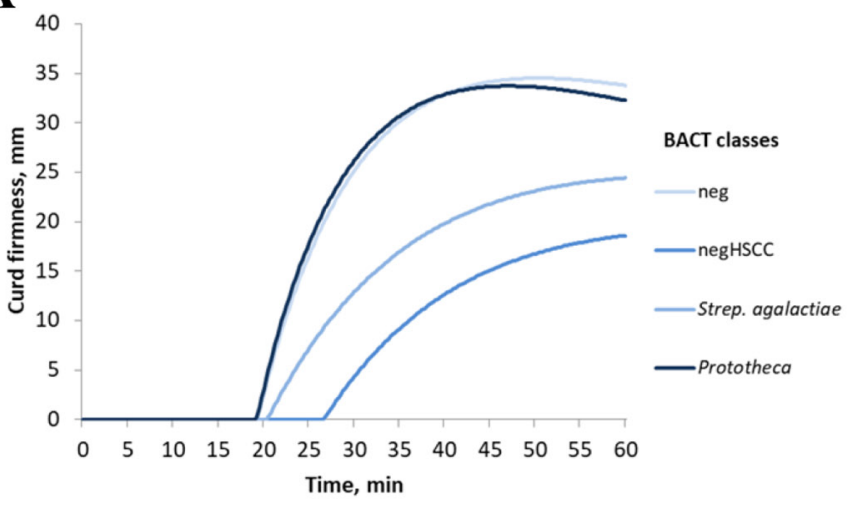

B

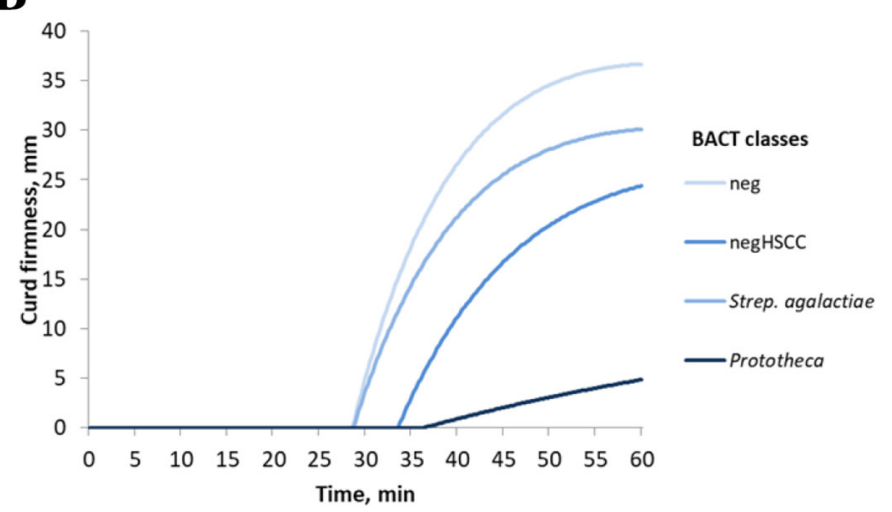

Figure 6. Pattern of curd firmness after rennet addition of milk samples according to bacteriological (BACT) status classes at (A) time 1 and (B) time 2. BACT classes were defined as follows: negative at bacteriological examination and SCC $<200,000$ cells $/ \mathrm{mL}$ (neg); negative at bacteriological examination and SCC $\geq 200,000$ cells/mL (negHSCC); positive at bacteriological examination for Streptococcus agalactiae; positive at bacteriological examination for Prototheca spp. 


\section{CONCLUSIONS}

Increased SCC and presence of IMI were associated with reduced milk quality, changes in udder health indicators, and detrimental effects on cheesemaking traits. The discrepancy between bacteriological and inflammatory status supported the usefulness of SCC as an udder health indicator, even in culture-negative milk samples. We have identified putative differential effects of Strep. agalactiae and Prototheca spp. on milk traits. Notably, Prototheca spp. was associated with milk that had greater impairment in milk quality and cheesemaking aptitude. Validation of these results in other and larger populations is required, as well as further investigation on the mechanisms underlying the mammary gland response to this pathogen.

\section{ACKNOWLEDGMENTS}

The research was part of the project LATSAN funded by the Ministero delle politiche agricole alimentari, forestali e del turismo (MIPAAF), Rome, Italy. The authors acknowledge the participation of Selene Massaro, Matteo Conte, Beatrice Barlocchi, Martina Piazza, Alice Vanzin and Giorgia Secchi (Department of Agronomy, Food, Natural Resources, Animals and Environment, University of Padova, Legnaro, Italy) for support during sampling activities and laboratory work, and Sofia Ton and Marco Franzoi from Breeders Association of Veneto Region (ARAV, Padova, Italy) for milk composition analyses. The authors have not stated any conflicts of interest.

\section{REFERENCES}

Abebe, R., H. Hatiya, M. Abera, B. Megersa, and K. Asmare. 2016. Bovine mastitis: Prevalence, risk factors and isolation of Staphylococcus aureus in dairy herds at Hawassa milk shed. BMC Vet. Res. 12:270. https://doi.org/10.1186/s12917-016-0905-3.

Åkerstedt, M., E. Wredle, V. Lam, and M. Johansson. 2012. Protein degradation in bovine milk caused by Streptococcus agalactiae. J. Dairy Res. 79:297-303. https://doi.org/10.1017/ S0022029912000301.

Ali, A. K. A., and G. E. Shook. 1980. An optimum transformation for somatic cell concentration in milk. J. Dairy Sci. 63:487-490. https: //doi.org/10.3168/jds.S0022-0302(80)82959-6.

Amalfitano, N., C. Cipolat-Gotet, A. Cecchinato, M. Malacarne, A. Summer, and G. Bittante. 2019. Milk protein fractions strongly affect the patterns of coagulation, curd firming, and syneresis. J. Dairy Sci. 102:2903-2917. https://doi.org/10.3168/jds.2018-15524.

Bittante, G., B. Contiero, and A. Cecchinato. 2013. Prolonged observation and modelling of milk coagulation, curd firming, and syneresis. Int. Dairy J. 29:115-123. https://doi.org/10.1016/J IDAIRYJ.2012.10.007.

Bobbo, T., C. Cipolat-Gotet, G. Bittante, and A. Cecchinato. 2016. The nonlinear effect of somatic cell count on milk composition, coagulation properties, curd firmness modeling, cheese yield, and curd nutrient recovery. J. Dairy Sci. 99:5104-5119. https://doi .org/10.3168/jds.2015-10512.
Bobbo, T., P. L. Ruegg, G. Stocco, E. Fiore, M. Gianesella, M. Morgante, D. Pasotto, G. Bittante, and A. Cecchinato. 2017. Associations between pathogen-specific cases of subclinical mastitis and milk yield, quality, protein composition, and cheese-making traits in dairy cows. J. Dairy Sci. 100:4868-4883. https://doi.org/10 $.3168 /$ jds.2016-12353.

Bradley, A. 2002. Bovine mastitis: An evolving disease. Vet. J. 164:116-128. https://doi.org/10.1053/tvjl.2002.0724.

Cipolat-Gotet, C., A. Cecchinato, M. De Marchi, and G. Bittante. 2013. Factors affecting variation of different measures of cheese yield and milk nutrient recovery from an individual model cheesemanufacturing process. J. Dairy Sci. 96:7952-7965. https://doi .org/10.3168/jds.2012-6516.

Cremonesi, P., C. Ceccarani, G. Curone, M. Severgnini, C. Pollera, V. Bronzo, F. Riva, M. F. Addis, J. Filipe, M. Amadori, E. Trevisi, D. Vigo, P. Moroni, and B. Castiglioni. 2018. Milk microbiome diversity and bacterial group prevalence in a comparison between healthy Holstein Friesian and Rendena cows. PLoS One 13:e0205054. https://doi.org/10.1371/journal.pone.0205054.

Curone, G., J. Filipe, P. Cremonesi, E. Trevisi, M. Amadori, C. Pollera, B. Castiglioni, L. Turin, V. Tedde, D. Vigo, P. Moroni, A. Minuti, V. Bronzo, M. F. Addis, and F. Riva. 2018. What we have lost: Mastitis resistance in Holstein Friesians and in a local cattle breed. Res. Vet. Sci. 116:88-98. https://doi.org/10.1016/j .rvsc.2017.11.020.

Damm, M., C. Holm, M. Blaabjerg, M. N. Bro, and D. Schwarz. 2017. Differential somatic cell count-A novel method for routine mastitis screening in the frame of Dairy Herd Improvement testing programs. J. Dairy Sci. 100:4926-4940. https://doi.org/10.3168/ jds.2016-12409.

Dosogne, H., F. Vangroenweghe, J. Mehrzad, A. M. Massart-Leën, and C. Burvenich. 2003. Differential leukocyte count method for bovine low somatic cell count milk. J. Dairy Sci. 86:828-834. https://doi .org/10.3168/jds.S0022-0302(03)73665-0.

Guinee, T. P. 2003. Role of protein in cheese products. Pages 1083 1159 in Advanced Dairy Chemistry, Vol. 1B: Proteins: Basic Aspects. 3rd ed. P. F. Fox and P. L. H McSweeney, ed. Springer.

Hauge, S., and J. K. Ellingsen. 1953. Selective agar medium (TKT Medium) for demonstration of group B streptococci in samples of producer milk. Nord. Vet. Med. 5:539-547.

International Dairy Federation. 2013. Guidelines for the use and interpretation of bovine milk somatic cell count. Bull. IDF 466 .

Irrgang, A., J. Murugaiyan, C. Weise, W. Azab, and U. Roesler. 2015. Well-known surface and extracellular antigens of pathogenic microorganisms among the immunodominant proteins of the infectious microalgae Prototheca zopfii. Front. Cell. Infect. Microbiol. 5:67. https://doi.org/10.3389/fcimb.2015.00067.

ISO. 1999. Standard 6888-2. International Organization for Standardization Microbiology of food and animal feeding stuffs - Horizontal method for the enumeration of coagulase-positive staphylococci (Staphylococcus aureus and other species) - Part 2: Technique using rabbit plasma fibrinogen agar medium.

Jagielski, T., Z. Bakuła, S. Di Mauro, C. Casciari, V. Cambiotti, H. Krukowski, B. Turchetti, M. Ricchi, E. Manuali, and P. Buzzini. 2017. A comparative study of the in vitro activity of iodopropynyl butylcarbamate and amphotericin B against Prototheca spp. isolates from European dairy herds. J. Dairy Sci. 100:7435-7445. https://doi.org/10.3168/jds.2017-12597.

Jagielski, T., K. Roeske, Z. Bakuła, T. Piech, Ł. Wlazło, M. Bochniarz, P. Woch, and H. Krukowski. 2019. A survey on the incidence of Prototheca mastitis in dairy herds in Lublin province, Poland. J. Dairy Sci. 102:619-628. https://doi.org/10.3168/jds.2018-15495.

Kandeel, S. A., A. A. Megahed, M. H. Ebeid, and P. D. Constable. 2019. Ability of milk $\mathrm{pH}$ to predict subclinical mastitis and intramammary infection in quarters from lactating dairy cattle. J. Dairy Sci. 102:1417-1427. https://doi.org/10.3168/jds.2018-14993.

Le Maréchal, C., R. Thiéry, E. Vautor, and Y. Le Loir. 2011. Mastitis impact on technological properties of milk and quality of milk products-A review. Dairy Sci. Technol. 91:247-282. https://doi .org/10.1007/s13594-011-0009-6. 
Le Roux, Y., F. Laurent, and F. Moussaoui. 2003. Polymorphonuclear proteolytic activity and milk composition change. Vet. Res. 34:629-645. https://doi.org/10.1051/vetres:2003021.

Leitner, G., E. Shoshani, O. Krifucks, M. Chaffer, and A. Saran. 2000. Milk leucocyte population patterns in bovine udder infection of different aetiology. J. Vet. Med. B Infect. Dis. Vet. Public Health 47:581-589. https://doi.org/10.1046/j.1439-0450.2000.00388.x.

Malek dos Reis, C. B., J. R. Barreiro, L. Mestieri, M. A. F. Porcionato, and M. V. dos Santos. 2013. Effect of somatic cell count and mastitis pathogens on milk composition in Gyr cows. BMC Vet. Res. 9:67. https://doi.org/10.1186/1746-6148-9-67.

National Mastitis Council (NMC). 2017. Laboratory Handbook on Bovine Mastitis. Rev. ed. National Mastitis Council Inc.

Norberg, E. 2005. Electrical conductivity of milk as a phenotypic and genetic indicator of bovine mastitis: A review. Livest. Prod. Sci. 96:129-139. https://doi.org/10.1016/j.livprodsci.2004.12.014.

Ogola, H., A. Shitandi, and J. Nanua. 2007. Effect of mastitis on raw milk compositional quality. J. Vet. Sci. 8:237-242. https://doi.org/ 10.4142/jvs.2007.8.3.237.

Paixão, M. G., L. R. Abreu, R. Richert, and P. L. Ruegg. 2017. Milk composition and health status from mammary gland quarters adjacent to glands affected with naturally occurring clinical mastitis. J. Dairy Sci. 100:7522-7533. https://doi.org/10.3168/jds.2017 $-12547$.

Pegolo, S., D. Giannuzzi, V. Bisutti, R. Tessari, M. E. Gelain, L. Gallo, S. Schiavon, F. Tagliapietra, E. Trevisi, P. Ajmone Marsan, G. Bittante, and A. Cecchinato. 2021. Associations between differential somatic cell count and milk yield, quality, and technological characteristics in Holstein cows. J. Dairy Sci. 104:4822-4836. https://doi.org/10.3168/jds.2020-19084.

Rajala-Schultz, P. J., Y. T. Gröhn, and C. E. McCulloch. 1999. Effects of milk fever, ketosis, and lameness on milk yield in dairy cows. J. Dairy Sci. 82:288-294. https://doi.org/10.3168/jds.S0022 $-0302(99) 75235-5$

Ruegg, P. L. 2017. A 100-Year Review: Mastitis detection, management, and prevention. J. Dairy Sci. 100:10381-10397. https://doi .org/10.3168/jds.2017-13023.

Salat, O., F. Sérieys, B. Poutrel, L. Durel, and L. Goby. 2008. Systemic treatment of subclinical mastitis in lactating cows with penethamate hydriodide. J. Dairy Sci. 91:632-640. https://doi.org/ $10.3168 /$ jds.2007-0174.

Sarikaya, H., G. Schlamberger, H. H. D. Meyer, and R. M. Bruckmaier. 2006. Leukocyte populations and mRNA expression of inflammatory factors in quarter milk fractions at different somatic cell score levels in dairy cows. J. Dairy Sci. 89:2479-2486. https://doi .org/10.3168/jds.S0022-0302(06)72322-0.
Schwarz, D., U. S. Diesterbeck, S. König, K. Brügemann, K. Schlez, M. Zschöck, W. Wolter, and C. P. Czerny. 2011. Flow cytometric differential cell counts in milk for the evaluation of inflammatory reactions in clinically healthy and subclinically infected bovine mammary glands. J. Dairy Sci. 94:5033-5044. https://doi.org/10 $.3168 /$ jds.2011-4348.

Sears, P. M., B. S. Smith, P. B. English, P. S. Herer, and R. N. Gonzalez. 1990. Shedding pattern of Staphylococcus aureus from bovine intramammary infections. J. Dairy Sci. 73:2785-2789. https://doi .org/10.3168/jds.S0022-0302(90)78964-3.

Seegers, H., C. Fourichon, and F. Beaudeau. 2003. Production effects related to mastitis and mastitis economics in dairy cattle herds. Vet. Res. 34:475-491. https://doi.org/10.1051/vetres:2003027.

Shave, C. D., L. Millyard, and R. C. May. 2021. Now for something completely different: Prototheca, pathogenic algae. PLoS Pathog. 17:e1009362-7. https://doi.org/10.1371/journal.ppat.1009362.

Stocco, G., C. Cipolat-Gotet, T. Bobbo, A. Cecchinato, and G. Bittante. 2017. Breed of cow and herd productivity affect milk composition and modeling of coagulation, curd firming, and syneresis. J. Dairy Sci. 100:129-145. https://doi.org/10.3168/jds.2016-11662.

Wawron, W., M. Bochniarz, T. Piech, W. Łopuszyński, and J. Wysocki. 2013. Outbreak of protothecal mastitis in a herd of dairy cows in Poland. Bull. Vet. Inst. Pulawy 57:335-339. https://doi .org/10.2478/bvip-2013-0058.

Wellnitz, O., and R. M. Bruckmaier. 2012. The innate immune response of the bovine mammary gland to bacterial infection. Vet. J. 192:148-152. https://doi.org/10.1016/j.tvjl.2011.09.013.

\section{ORCIDS}

S. Pegolo @ https://orcid.org/0000-0001-6390-9826

D. Giannuzzi @ https://orcid.org/0000-0003-2975-0385

M. Gianesella (ㄴ) https://orcid.org/0000-0001-8117-5969

A. Lisuzzo @ https://orcid.org/0000-0001-7064-0749

E. Fiore $\odot$ https://orcid.org/0000-0002-0377-9553

A. Barberio (으 https://orcid.org/0000-0002-3108-8354

E. Trevisi @ https://orcid.org/0000-0003-1644-1911

F. Piccioli Cappelli @ (ttps://orcid.org/0000-0003-1277-7821

L. Gallo (® https://orcid.org/0000-0002-8908-5105

P. Ruegg (ㄴ) https://orcid.org/0000-0002-7211-4512

A. Cecchinato $\odot$ https://orcid.org/0000-0003-3518-720X 